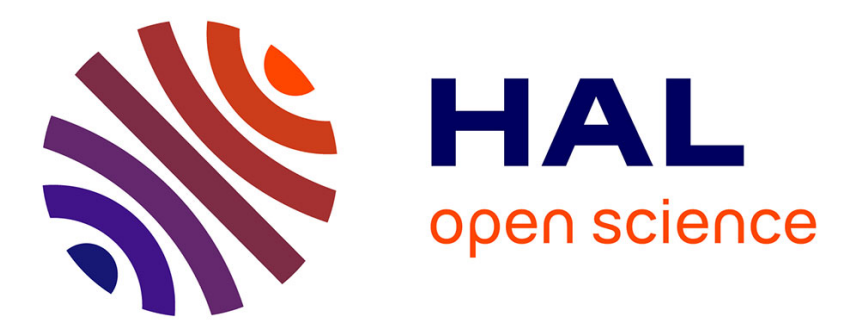

\title{
The carbon dioxide solubility in alkali basalts: an experimental study
}

Priscille Lesne, Bruno Scaillet, Michel Pichavant, Jean-Michel Bény

\section{To cite this version:}

Priscille Lesne, Bruno Scaillet, Michel Pichavant, Jean-Michel Bény. The carbon dioxide solubility in alkali basalts: an experimental study. Contributions to Mineralogy and Petrology, 2011, 162 (1), pp.153-168. 10.1007/s00410-010-0585-0 . insu-00534729

\section{HAL Id: insu-00534729 \\ https://hal-insu.archives-ouvertes.fr/insu-00534729}

Submitted on 28 Jan 2011

HAL is a multi-disciplinary open access archive for the deposit and dissemination of scientific research documents, whether they are published or not. The documents may come from teaching and research institutions in France or abroad, or from public or private research centers.
L'archive ouverte pluridisciplinaire HAL, est destinée au dépôt et à la diffusion de documents scientifiques de niveau recherche, publiés ou non, émanant des établissements d'enseignement et de recherche français ou étrangers, des laboratoires publics ou privés.

\section{(1) (1) $\$$}

Distributed under a Creative Commons Attribution - NonCommercial - NoDerivatives| 4.0 


\title{
The carbon dioxide solubility in alkali basalts: an experimental
}

\author{
study
}

Priscille LESNE $^{1, *}$, Bruno SCAILlET ${ }^{1}$, Michel PiCHAVANT ${ }^{1}$, JeAN-Michel BENY ${ }^{1}$

${ }^{1}$ CNRS/INSU-Université d'Orléans-Université François Rabelais Tours, UMR 6113, Institut des Sciences de la Terre d'Orléans, 1A, rue de la Férollerie, 45071 Orléans Cedex 02, France

\author{
*Corresponding author: \\ e-mail: P.Lesne@bristol.ac.uk
}

present address: Department of Earth Sciences, University of Bristol, Wills Memorial Building, Queens Road, Bristol, BS8 1RJ, U.K.

\begin{abstract}
:
Experiments were conducted to determine $\mathrm{CO}_{2}$ solubilities in alkali basalts from Vesuvius, Etna and Stromboli. The basaltic melts were equilibrated with nearly pure $\mathrm{CO}_{2}$ at $1200^{\circ} \mathrm{C}$ under oxidizing conditions, and at pressures ranging from 269 to 2060 bars. $\mathrm{CO}_{2}$ solubility was determined by FTIR measurements. The results show that alkalis have a strong effect on the $\mathrm{CO}_{2}$ solubility and confirm and refine the relationship between the compositional parameter $\Pi$ devised by Dixon (1997) and the $\mathrm{CO}_{2}$ solubility. A general thermodynamic model for $\mathrm{CO}_{2}$ solubility in basaltic melts is defined for pressures up to $2 \mathrm{kbars}$. The new $\mathrm{CO}_{2}$ solubility model yields saturation pressures lower by as much as $50 \%$ relative to existing models when applied to volatile-rich alkali basalts.
\end{abstract}

Key words: $\mathrm{CO}_{2}$ solubility, alkali basalts, experiments, thermodynamics 


\section{Introduction}

Dissolved volatiles in silicate melts dramatically influence the physical properties of magmas, such as density, viscosity, vesiculation, and largely control eruptive styles. Volatiles exsolve from melts into bubbles as magmas rise toward the earth's surface and depressurize (e.g., Blank et al., 1993). Such a process may give rise to explosive eruptions, leading to important human and material damages, and may have a major impact on the global Earth climate (Robock 2000). Water is generally the most abundant volatile in terrestrial magmas, $\mathrm{CO}_{2}$ being the second most common species, notably in mafic compositions. Thus, understanding the thermodynamics of $\mathrm{CO}_{2}$ in silicate melts can provide important constraints on the behaviour of basaltic reservoirs, the ensuing eruptive processes, and ultimately on the evolution of planetary degassing. To model basalt degassing during volcanic eruptions, a detailed knowledge of the mixing properties of volatile components in both fluid and melt is required since, because of its low solubility, carbon dioxide is usually a major component of the gases escaping from magmas as they rise through the crust.

Experiments on $\mathrm{CO}_{2}$ solubility in basaltic melts have been performed mostly at high pressures where dissolved $\mathrm{CO}_{2}$ contents may reach several wt\% (>10 kbar, Blank and Brooker, 1994, Morizet et al., 2002). At lower pressures, efforts have mainly focused on silicic liquids and only a few studies have been performed on $\mathrm{CO}_{2}$ solubility in basaltic melts (e.g., Pawley et al., 1992, Dixon et al., 1995, Jendrzejewki et al., 1997; Behrens et al., 2009). As pointed out by Stolper and Holloway (1988), this gap of knowledge reflects in part the small influence of $\mathrm{CO}_{2}$ on solid-liquid phase equilibria at low pressures, due to its low solubility in most silicate melts under such conditions. Another reason is the technical difficulties associated with the need to work at the high temperature conditions required for mafic compositions (e.g., Berndt et al., 2002; Di Carlo et al., 2006; Behrens et al., 2009), in particular in the mid pressure range (2-6 kbar) where solid pressure media, such as piston cylinders, are not routinely operated. More specifically, the low viscosity of mafic melts requires them to be fast quenched to prevent their crystallisation during cooling. This demands the implementation of appropriate experimental designs in gas pressure vessels (Holloway et al., 1992; Roux and Lefevre, 1992) and, for $\mathrm{H}_{2} \mathrm{O}$-bearing basalts, such devices may still fail to properly quench liquids to glasses (e.g., Behrens et al., 2009). As a consequence of these technical difficulties, the number of high quality solubility data in the low to mid pressure range has remained limited. In particular, alkali basalt compositions have received limited attention. Petrological studies indicate, however, that such alkali-rich compositions are volatile-rich, in particular in arc 
settings (Dixon et al., 1997; Métrich et al., 2001; Bertagnini et al., 2004). Experimental data show indeed that alkali-rich basalt compositions tend to dissolve more $\mathrm{CO}_{2}$ than those alkalipoor (Dixon, 1997; Botcharnikov et al., 2005; Behrens et al, 2009), a key role being played by potassium (Behrens et al., 2009) but the exact compositional control of such an increase is still unclear.

In an effort to decipher the role of alkalis on $\mathrm{CO}_{2}$ solubility, in this study we report measurements of $\mathrm{CO}_{2}$ solubility obtained in several basalts of varying alkalinity coming from Italian active volcanoes at $1200^{\circ} \mathrm{C}$, at pressures ranging from 250 up to $2000 \mathrm{bar}$, and under oxidizing conditions. $\mathrm{CO}_{2}$ contents in quenched glasses from vapour-saturated experiments were measured by infrared spectroscopy. Solubility measurements give upper bounds on the amounts of $\mathrm{CO}_{2}$ that can dissolve in magmas at various temperatures and pressures. $\mathrm{A}$ companion paper presents the thermodynamics of water in these silicate melts. Our aim is to produce a set of internally consistent data on the solubility of C-O-H-S volatiles under moderately oxidizing conditions so as to be ultimately able to quantitatively model the degassing of alkali basalts, such as recently done for silicic compositions by Burgisser and Scaillet (2007).

\section{Experimental techniques}

\section{Starting materials, capsules and charges}

Three alkali basalts from Vesuvius, Etna and Stromboli (Lesne et al. this issue) were selected for our investigation. The natural samples were powdered and melted in a Pt crucible at atmospheric pressure, at $1400^{\circ} \mathrm{C}$ during 3 hours in order to get homogeneous and nominally anhydrous glasses. The resulting glasses were analyzed by electron microprobe. Their compositions are listed in Table 1. Experiments were conducted in parallel on those three alkali basalts.

As for experiments on water solubility, small glass chips were loaded in capsules to prevent bubble formation. About 60 to $100 \mathrm{mg}$ of starting material was used for each experiment. Capsules ( $2 \mathrm{~cm}$ height, $2.5 \mathrm{~mm}$ inner and $2.9 \mathrm{~mm}$ outer diameters) made of platinum were used. $\mathrm{CO}_{2}$ was added as silver oxalate $\left(\mathrm{Ag}_{2} \mathrm{C}_{2} \mathrm{O}_{4}\right.$, density $\left.5 \mathrm{~g} / \mathrm{cm}^{3}\right)$. Although silver does dissolve in basaltic melt, its effect on $\mathrm{CO}_{2}$ solubility has been shown to be negligible (Pan et al., 1991). Capsules were sealed by electric arc. They sere then put in an oven for several hours and reweighed to check for leaks. 


\section{Equipment and experiments}

Equilibrium experiments between a fluid $\left(\mathrm{CO}_{2}\right.$-rich fluids, see below) and a silicate liquid phase were conducted in an internally heated pressure vessel (IHPV) operated in a vertical position and equipped with a drop quench set up (see Di Carlo et al., 2006). Experiments were performed at $1200 \pm 5^{\circ} \mathrm{C}$, at the following pressures: $269,524,1013,1062,1128,2059 \pm 25$ bars, under oxidizing conditions. Experiments lasted between 4 to 8 hours. Based on previous experimental works performed using similar procedures, the equilibrium between the basaltic liquid and the fluid phase is considered to be reached under these conditions (e.g., Dixon et al, 1995; Botcharknikov et al, 2005; Behrens et al., 2009). Phase equilibrium experiments performed with the same duration and $\mathrm{P}-\mathrm{T}-\mathrm{H}_{2} \mathrm{O}-\mathrm{CO}_{2}$ conditions (Di Carlo et al., 2006; Pichavant et al. 2009) on a Strombolian basalt had no problem in attaining crystal-liquid equilibrium. Since the kinetics of melt-fluid equilibrium is faster than that of crystal-liquid one, we conclude that our run durations were long enough to attain equilibrium. In support of this, major element analyses performed on two or three glass ships on microprobe yielded the same results within analytical error. The same was observed with FTIR analyses carried out on several double polished glass pieces (2 to 3 ).

Any use of sensor was not possible because of the short duration of the experiments. All the runs were done using the intrinsic $\mathrm{fH}_{2}$ of the vessel, as measured by Pichavant et al. (2009) for experiments done with the same apparatus, without hydrogen added, at $1150^{\circ} \mathrm{C}$, at 2010 and 880 bars (runs 22 and 23). We assume that the $\mathrm{fH}_{2}$ measured in those experiments is equivalent to the $\mathrm{fH}_{2}$ in our runs, then the $\mathrm{fO}_{2}$ of each charge was calculated from the dissociation reaction of water, using $\mathrm{fH}_{2} \mathrm{O}$ as calculated from the dissolved water content in the glass (see below). It appears that the $\mathrm{fO}_{2}$ calculated for all charges, averages at $\mathrm{NNO}+1.9$, with an error of $0.6 \log$ unit. All performed experiments for this study are reported in Table 2.

\section{Analytical techniques}

Analytical techniques used in this study are the same as those used in the accompanying paper (Lesne et al.). Major elements were analysed with a SX50 CAMECA electron microprobe (BRGM-ISTO, Orléans, France). Water contents and its speciation were determined with FTIR analyses. All of these methods are described in detail in Lesne et al. (this issue). The total carbon dissolved in quenched glasses was determined by using transmission IR spectroscopy on doubly polished glass chips, with thicknesses varying between 60 and 270 $\mu \mathrm{m}$. One sample (4\#4) had very low $\mathrm{CO}_{2}$ contents, which required the use of a thick double polished glass $(370 \mu \mathrm{m})$.. Sample thicknesses were measured using an optical microscope to 
within $3 \mu \mathrm{m}$. To determine the total carbon dissolved in the glass, a microchamber attachment to the FTIR Nicolet ${ }^{\mathrm{TM}}$ Magna Spectrometer 760 together with a white source, a $\mathrm{KBr}$ beamsplitter and a MCT-A detector (mercury, cadmium tellurium) were used. Analytical conditions for each analysis were 128 scans and a $2 \mathrm{~cm}^{-1}$ resolution. The diameter of the analyzed spot was $100 \mu \mathrm{m}$. The background was acquired in air at each measurement. For each sample, a minimum of 2 spots were made, in order to check the homogeneity of the sample.

Carbon can be dissolved in silicate melts either as molecular $\mathrm{CO}_{2}$ or as carbonate groups $\mathrm{CO}_{3}{ }^{2-}$ (e.g., Fine and Stolper, 1985, 1986, Morizet et al., 2002). The intensity of the $2350 \mathrm{~cm}-$ 1 is attributed to the $v_{3}$ antisymmetric stretch of molecular $\mathrm{CO}_{2}$ (Fine and Stolper, 1985; Fine and Stolper, 1986). The peaks at $1515 \mathrm{~cm}^{-1}$ and $1435 \mathrm{~cm}^{-1}$ correspond to an antisymmetric stretch of distorted $\mathrm{CO}_{3}{ }^{2-}$ groups (Fine and Stolper, 1986). Figure 1 shows a typical IR spectrum obtained on our glasses which shows that there is a double peak at $1515 \mathrm{~cm}-1$ and $1435 \mathrm{~cm}-1$, whilst none is present at $2350 \mathrm{~cm}^{-1}$. Thus, the carbon dissolved in the melt is present as carbonate groups $\left(\mathrm{CO}_{3}^{2-}\right)$ only, in agreement with previous works on basaltic compositions (e.g., Pan et al., 1991; Behrens et al., 2009).

In this work, following Behrens et al. (2009), we measured carbonate absorbance by substracting from the sample spectrum that of a compositionally similar but volatile-free glass (ie the starting dry glass) scaled to the same thickness of the unknown. This enables to model the background and measure the peak height of the $1515 \mathrm{~cm}^{-1}$ wavenumber.

The total carbon content of glasses was calculated with the Beer-Lambert law (Fine and Stolper 1985;1986), by measuring the absorbance of the $1515 \mathrm{~cm}^{-1}$ band:

$$
C_{\mathrm{CO}_{2}}=\frac{A_{1515} * M_{\mathrm{CO}_{2}}}{d^{*} \rho^{*} \varepsilon_{1515}}
$$

Where $C_{\mathrm{CO}_{2}}$ is the total carbon content in the glass (in wt\%), $\mathrm{A}_{1515}$ is the absorbance of the $1515 \mathrm{~cm}^{-1}$ band, $\mathrm{d}$ is the thickness of the sample (in $\mathrm{cm}$ ), $\rho$ is the density in $\mathrm{g} . \mathrm{l}^{-1}, \varepsilon_{1515}$ is the molar extinction coefficient $\left(1 . \mathrm{mol}^{-1} \cdot \mathrm{cm}^{-1}\right)$, and $\mathrm{M}_{\mathrm{CO}_{2}}$ is the molecular weight of $\mathrm{CO}_{2}$.

Glass densities, were calculated using the method of Richet et al. (2000), considering only the amount of water dissolved in the glass, assuming that the small quantities of $\mathrm{CO}_{2}$ dissolved do not affect density to any measurable extent (Lange, 1994, Bourgue and Richet, 2001).

The choice of appropriate molar extinction coefficients is crucial to measure correctly dissolved carbon contents (e.g. Behrens et al., 2009). However, we do not have bulk carbon data, and thus it is not possible to obtain molar extinction coefficients for each basaltic 
compositions studied here. Consequently, two choices are offered: either we arbitrarily take the same value for the three basaltic compositions, referring to Fine and Stolper $(1986)\left(\varepsilon_{1515}\right.$ $=375 \pm 201 . \mathrm{mol}^{-1} \cdot \mathrm{cm}^{-1}$, calculated for basaltic glasses), or we calculate the extinction coefficient for each basaltic melt using the method of Dixon and Pan (1995). These authors found a linear dependency of the molar extinction coefficient with the $\mathrm{Na} /(\mathrm{Na}+\mathrm{Ca})$ molar ratio, in the range 0.25 to 0.5 . Values of molar extinction coefficients determined by Dixon and Pan's method yield $3811 . \mathrm{mol}^{-1} \cdot \mathrm{cm}^{-1}$ for Vesuvius, $3271 . \mathrm{mol}^{-1} \cdot \mathrm{cm}^{-1}$ for Etna and 367 $1 . \mathrm{mol}^{-1} . \mathrm{cm}^{-1}$ for Stromboli samples. The calculated extinction coefficients for both Vesuvius and Stromboli are within $2 \%$ of the Fine and Stolper (1986) value, whilst that for Etna is lower by $13 \%$, which reflects its higher Na content.. Behrens et al. (2009) determined the extinction coefficient of their phonotephrite melt to be $308 \pm 1101 . \mathrm{mol}^{-1} . \mathrm{cm}^{-1}$, whilst the value retrieved with the Dixon and Pan (1995) method is $3701 . \mathrm{mol}^{-1} \cdot \mathrm{cm}^{-1}$. Although both values agree within error, the difference observed suggests that the Dixon and Pan method may overestimate extinction coefficients of strongly potassic compositions by up to $20 \%$, which translates into a similar overestimates of carbon contents calculated with the Beert-Lambert law. In the following, owing to the lack of absolute method to measure dissolved $\mathrm{C}$ content, and considering the significant errors associated to existing measurements of extinction coefficients for basaltic compositions, we first present the results obtained by using the same extinction coefficient for all compositions, and latter discuss the effect arising from the use of composition specific molar extinction coefficients .

In addition to the uncertainty on extinction coefficients, one of the largest sources of errors in measuring the total carbon dissolved in the melt by FTIR arises from the method chosen to model the background. The method used here is somewhat subjective and leads to an error in absorbance estimated to be \pm 0.015 , which propagates into an error of $\pm 50 \mathrm{ppm}$ of the $\mathrm{CO}_{2}$ dissolved in the glass, regardless of the $\mathrm{CO}_{2}$ contents. Thicknesses were measured to within 3 $\mu \mathrm{m}$ which induces an error of $2 \%$ on the total $\mathrm{CO}_{2}$ contents dissolved in the melt. The maximum error on the density calculations is equal to $20 \%$. Altogether we estimate that the $\mathrm{CO}_{2}$ content reported in this work are known to within $20 \%$.

\section{Results}

The fluid-saturated charges have been checked after each experiment: capsules were first weighed to check any volatile loss during experiment, then they were punctured. Any escape of bubbles/gas and difference of weigh between before and after piercing is a proof of fluidsaturated experiment. All the data presented in this study are fluid saturated. 


\section{Macro and microscopic observations}

Run products were translucent to brownish glasses, becoming darker and opaque when quench crystals $(<5 \mu \mathrm{m})$ were present (i.e., in experiments performed with more than 4 capsules). Most quenched glasses contain a few microbubbles whose abundance does not exceed $0.1 \%$ in volume. Larger bubbles $(<0.5 \mathrm{~mm}$ of diameter), indicative of fluid saturation at $\mathrm{P}$ and $\mathrm{T}$, are located at the melt/capsule interface, as shown by the presence of large open smooth cavities at the surface of the glass blocks.

\section{Major elements and $\mathrm{H}_{2} \mathrm{O}$ contents}

The compositions of quenched glasses are reported in the Table 3. Analytical errors were less than $0.2 \%$ for all oxides, except for $\mathrm{SiO}_{2}(0.4$ to $0.6 \%)$ and for $\mathrm{Fe}_{\text {tot }}$ (less than $0.4 \%$ ). Apart from $\mathrm{Fe}_{\text {tot }}$, the concentrations of major oxides do not differ appreciably from those of the starting materials (Table 1).

For experiments carried out in platinum capsules, the iron loss is around $30 \%$, whereas the iron loss of experiments carried out in $\mathrm{Au}_{75} \mathrm{Pd}_{25}$ capsules is less than $10 \%$ (Table 3 ).

Despite that no water was added to the capsules, the water contents of quenched glasses vary between 0.70 and $1.30 \mathrm{wt} \%$ without any obvious relationships with pressure or melt composition. Several sources of water can be proposed: it could come from the silver oxalate which contains some water (up to $5 \mathrm{wt} \%$ ) and could not be dried enough, or from adsorption of atmospheric water on the starting glasses. However, the most probable source of $\mathrm{H}_{2} \mathrm{O}$ is from reduction of ferric into ferrous iron (e.g., Holloway et al., 1992), inasmuch as our starting glasses are oxidized, which enables the operation of the following reaction:

$$
\mathrm{Fe}_{2} \mathrm{O}_{3}+\mathrm{H}_{2} \Leftrightarrow \mathrm{FeO}+\mathrm{H}_{2} \mathrm{O} \text { (2). }
$$

Note that, in addition to the above reaction, reduction of ferrous iron via alloying with the capsule wall will also produce some water.

\section{$\mathrm{CO}_{2}$ contents}

Dissolved $\mathrm{CO}_{2}$ contents in glasses are reported in Table 3. We stress that, as the quenched glasses also contain dissolved $\mathrm{H}_{2} \mathrm{O}$, the measured $\mathrm{CO}_{2}$ contents do not represent pure $\mathrm{CO}_{2}$ solubilities. The data show linear relationships between dissolved carbon and pressure for each composition (figure 2). Data from Dixon et al. (1995) and Behrens et al. (2009) are also shown for comparison. Figure 2 shows clearly that there is a strong dependence of the carbon dissolved in the melt on melt composition. Alkali-rich compositions dissolve more $\mathrm{CO}_{2}$ than 
those alkali-poor. However, to rigorously compare $\mathrm{CO}_{2}$ solubilities of the different melt compositions, one has to determine the fugacities of $\mathrm{CO}_{2}$.

\section{Determination of the fugacities of $\mathrm{CO}_{2}$.}

As the $\mathrm{H}_{2} \mathrm{O}$ of quenched glasses was determined in each charge, and as solubilities laws of water were defined for each composition in the companion paper (Lesne et al.), we can calculate the $f_{\mathrm{H}_{2} \mathrm{O}}$ of each charge, using the following empirical relationships derived from the experimental data base of Lesne et al. (this issue):

$$
\begin{array}{ll}
f_{\mathrm{H}_{2} \mathrm{O}}^{1200^{\circ} \mathrm{C}}=126.54 \times\left(w t \% \mathrm{H}_{2} \mathrm{O}\right)^{1.69} & \text { for Vesuvius } \\
f_{\mathrm{H}_{2} \mathrm{O}}^{1200^{\circ} \mathrm{C}}=104.98 \times\left(w t \% \mathrm{H}_{2} \mathrm{O}\right)^{1.83} & \text { for Etna; } \\
f_{\mathrm{H}_{2} \mathrm{O}}^{1200^{\circ} \mathrm{C}}=128.49 \times\left(w t \% \mathrm{H}_{2} \mathrm{O}\right)^{1.73} & \text { for Stromboli. }
\end{array}
$$

In the above equations $w t \% \mathrm{H}_{2} \mathrm{O}$ is the $\mathrm{wt} \%$ amount of total water dissolved in the quenched glasses. Once the $f_{\mathrm{H}_{2} \mathrm{O}}$ is known, we can derive the mole fraction of $\mathrm{H}_{2} \mathrm{O}\left(X_{\mathrm{H}_{2} \mathrm{O}}^{f}\right)$ in the coexisting fluid by using the standard relationships:

$$
f_{i}=\gamma_{i} * P_{i}(6)
$$

where $\gamma_{i}$ is the fugacity coefficient of species $i$, and $P_{i}$ its partial pressure.

Since

$P_{i}=X_{i}^{*} P_{\text {tot }}(7)$, where $P_{\text {tot }}$ is total pressure,

we obtain

$$
f_{i}=\gamma_{i} * X_{i} * P_{t o t}(8)
$$

Assuming that the fluid is made of only $\mathrm{H}_{2} \mathrm{O}$ and $\mathrm{CO}_{2}$ species (under oxidized conditions $\mathrm{CO}_{2}$ has been shown to be the only C-bearing species in the C-O-H system, Pawley et al., 1992), it follows:

$$
X_{\mathrm{H}_{2} \mathrm{O}}+X_{\mathrm{CO}_{2}}=1(9) \text {, }
$$

and so

$$
X_{\mathrm{CO}_{2}}=1-X_{\mathrm{H}_{2} \mathrm{O}}(10) \text {. }
$$

In this work, we use the $\gamma_{\mathrm{CO}_{2}}$ and $\gamma_{\mathrm{H}_{2} \mathrm{O}}$ values of Dixon et al. (1995). These fugacity coefficients correspond to those of pure species at P and T. Strictly speaking, the fugacity coefficient of any species $i$ in a complex fluid is dependent on the composition of that fluid, in addition to $\mathrm{P}$ and $\mathrm{T}$, and this can be accounted for via the use of a modified Redlich Kwong equation of state with appropriate mixing rules between different fluid species (Holloway, 
1987; Ferry and Baumgartner, 1987). However, in the low pressure and high temperature range of interest here, application of the rules of real mixing of real fluid has only a trivial effect on the calculated fugacity coefficients (less than $1 \%$, see Holloway, 1977), relative to the assumption of ideal mixing of real fluids (Lewis and Randall rule) which has thus been used here for simplicity. Application of the empirical relationships 2-4 assumes also that dissolved $\mathrm{CO}_{2}$ does not affect the thermodynamics of $\mathrm{H}_{2} \mathrm{O}$ solution in the selected melts. Considering the low concentration in $\mathrm{CO}_{2}$ of our synthetic melts, this assumption holds true to a first approximation. The reverse (ie $\mathrm{H}_{2} \mathrm{O}$ affects the $\mathrm{CO}_{2}$ solubility) might not be true, however, as discussed below. Using such an approach, the fugacity of $\mathrm{CO}_{2}$ of any run product can be calculated in a way that ensures internal consistency between fluid species fugacities:

$$
f_{\mathrm{CO}_{2}}=\gamma_{\mathrm{CO}_{2}} \times X_{\mathrm{CO}_{2}} \times P_{\text {tot }}(11) \text {. }
$$

The relationships between dissolved $\mathrm{CO}_{2}\left(X_{\mathrm{CO}_{2}}^{m}\right.$ being the mole fraction of $\mathrm{CO}_{2}$ dissolved calculated following Silver and Stolper (1985) on the basis of one oxygen) and $f_{\mathrm{CO}_{2}}$ are shown in figure 3.

Each trend can be fitted to a second order polynomial equation, in mole fractions:

$$
\begin{aligned}
& f_{\mathrm{CO}_{2}}^{1200^{\circ} \mathrm{C}}=8.57 \times 10^{6} \times X_{\mathrm{CO}_{2}}^{m}{ }^{1.26} ; \quad \mathrm{R}^{2}=0.99 \text { for Vesuvius } \\
& f_{\mathrm{CO}_{2}}^{1200^{\circ} \mathrm{C}}=1.14 \times 10^{7} \times X_{\mathrm{CO}_{2}}^{m}{ }^{1.23} ; \quad \mathrm{R}^{2}=0.93 \text { for Etna } \\
& f_{\mathrm{CO}_{2}}^{1200^{\circ} \mathrm{C}}=3.49 \times 10^{6} \times X_{\mathrm{CO}_{2}}^{m}{ }^{1.04} ; \quad \mathrm{R}^{2}=0.99 \text { for Stromboli }
\end{aligned}
$$

or in ppm:

$$
\begin{aligned}
& f_{\mathrm{CO}_{2}}^{1200{ }^{\circ} \mathrm{C}}=1.93 \times 10^{-1} \times \mathrm{CO}_{2}^{\text {melt }}{ }^{1.26} ; \quad \mathrm{R}^{2}=0.99 \text { for Vesuvius } \\
& f_{\mathrm{CO}_{2} \mathrm{C}}^{120{ }^{\circ} \mathrm{C}}=4.06 \times 10^{-1} \times \mathrm{CO}_{2}^{\text {melt }}{ }^{1.22} ; \quad \mathrm{R}^{2}=0.93 \text { for Etna } \\
& f_{\mathrm{CO}_{2}}^{120{ }^{\circ} \mathrm{C}}=1.62 \times \mathrm{CO}_{2}^{\text {melt }}{ }^{1.04} ; \quad \mathrm{R}^{2}=0.99 \text { for Stromboli }
\end{aligned}
$$

$f_{\mathrm{CO}_{2}}$ versus $\mathrm{CO}_{2}^{\text {melt }}$ relationships for MORB (Dixon et al., 1995) is also shown on figure 3: the $\mathrm{CO}_{2}$ solubility varies non-linearly with fluid composition. Again, the dependence of the total dissolved carbon with melt composition is apparent. It should be stressed that equations 12-17 are essentially valid for the selected melt compositions having dissolved water contents similar to those of the present work and over the pressure range investigated (1-2 wt $\%$ and up to $2 \mathrm{~kb}$ ). On figure 3 we have also plotted the data of Behrens et al (2009), calculating the $\mathrm{fCO}_{2}$ using their measured $\mathrm{XCO}_{2}$ and equation (11). Despite some scatter, in part related to 
quench effects arising from the excessively low viscosity of phonotephrite melt, the data display a similar exponential pattern, being located to the right of the Vesuvius trend, which is in keeping with the much stronger potassic character of the phonotephrite composition (7.52 $\mathrm{wt} \% \mathrm{~K}_{2} \mathrm{O}$ ) used by Behrens et al. (2009) relative to any of our melt compositions.

\section{Discussion}

\section{Effect of alkalis}

Our results show clearly that alkalis have a positive effect on $\mathrm{CO}_{2}$ solubility in basaltic melts as shown by previous studies (e.g., Dixon 1997; Behrens et al. 2009).

At any investigated pressure, the tephrite from Vesuvius dissolves 1.4 more $\mathrm{CO}_{2}$ than the Etnean basalt, and 1.7 more $\mathrm{CO}_{2}$ than the Strombolian basalt, and up to 2 times more $\mathrm{CO}_{2}$ than a MORB (Dixon et al., 1995). This general trend is confirmed and extended by the data of Behrens et al. (2009). This effect is illustrated in figure 4: for each isobar, there exists a positive relationship between $\mathrm{CO}_{2}$ solubility and the alkalinity of the melt.

These results were obtained using the same extinction coefficients for the three basaltic compositions. If we consider now different extinction coefficients for our three basaltic melt compositions, using the method of Dixon and Pan (1995), we obtain similar results to those obtained with the molar extinction coefficient of Fine and Stolper (1986) for VES-9 (2\% lower) and PST-9 (2\% higher). Only for ETN-1 are the results obtained with the Dixon and Pan method different, compared to those obtained with the constant extinction coefficient. This is simply explained by the fact that Dixon and Pan (1995) method takes into account of the $\mathrm{Ca}$ and $\mathrm{Na}$ contents, the concentration in the latter element being higher in the Etnean composition relative to the two other basaltic compositions. However, regardless of which extinction coefficient is used (constant or specific to each composition), the same effect of alkalis is observed with pressure: VES-9 dissolves more $\mathrm{CO}_{2}$ than ETN-1 and then than PST9. We thus conclude that alkalis $\left(\mathrm{Na}_{2} \mathrm{O}+\mathrm{K}_{2} \mathrm{O}\right)$ have broadly a positive effect on the $\mathrm{CO}_{2}$ solubility in basaltic melts (see also King and Holloway, 2002). In the following, we consider the $\mathrm{CO}_{2}$ solubility results obtained by using the molar extinction coefficient of by Fine and Stolper (1986).

\section{Refinement of the model of Dixon (1997)}

Dixon (1997) used experimentally measured solubilities of $\mathrm{CO}_{2}$ in alkali basalts (composition from a MORB to a leucitite) to propose a method to rationalise the influence of melt 
composition on $\mathrm{CO}_{2}$ solubility. Dixon (1997) defined a compositional parameter $\Pi$ which takes into account the roles of $\mathrm{Si}^{4+}, \mathrm{Al}^{3+}, \mathrm{Ca}^{2+}, \mathrm{K}^{+}, \mathrm{Na}^{+}, \mathrm{Mg}^{2+}$ and $\mathrm{Fe}^{2+}$ cation fractions:

$$
\Pi=-6.50\left(\mathrm{Si}^{+4}+\mathrm{Al}^{+3}\right)+20.17\left(\mathrm{Ca}^{+2}+0.8 \mathrm{~K}^{+1}+0.7 \mathrm{Na}^{+1}+0.4 \mathrm{Mg}^{+2}+0.4 \mathrm{Fe}^{+2}\right)
$$

With this factor, the solubility of $\mathrm{CO}_{2}$ in alkali-rich basalts can be predicted at $1200^{\circ} \mathrm{C}$ and 1000 bars. $\mathrm{CO}_{2}$ solubilities for our three compositions at $1200^{\circ} \mathrm{C}$ and 1000 bars are plotted against the factor $\Pi$ and show a good agreement with the linear relationship predicted by Dixon (1997) (figure 6). Also represented is the composition of Behrens et al (2009), obtained from linear extrapolation to $1 \mathrm{kbar}$ of the results obtained by these authors at 2 and $5 \mathrm{kbar}$ (which yields at $1 \mathrm{kbar}$ a $\mathrm{CO}_{2}$ content of $767 \mathrm{ppm}$ ).

Overall, the available experimental data base supports the parameterisation between $\mathrm{CO}_{2}$ solubility and the $\Pi$ factor proposed by Dixon (1997) at $1200^{\circ} \mathrm{C}$ and 1000 bar as a useful tool for the description of $\mathrm{CO}_{2}$ solubility in basalt melts of variable alkalinity. At $1 \mathrm{kbar}$ and $1200^{\circ} \mathrm{C}$, the extended data base yields the following equation:

$$
\mathrm{CO}_{2}(\mathrm{ppm})=920( \pm 1) \Pi-17( \pm 53), \quad \mathrm{R}^{2}=0.89
$$

$\mathrm{CO}_{2}$ solubilities at 1000 bars calculated with equation (20) are slightly lower $(<10 \%)$ than the $\mathrm{CO}_{2}$ solubilities calculated by using the former regression coefficients of Dixon (1997). Calculating the $\mathrm{CO}_{2}$ solubility with the new regression, and comparing to actual $\mathrm{CO}_{2}$ contents, differences are less than 15\% for both VES-9 and PST-9, whilst for the Etna composition the back calculated values may differ by up to $30 \%$. Despite such an uncertainty equation (20) can be used to predict to a first approximation the $\mathrm{CO}_{2}$ solubility of basaltic magmas of different alkali contents at $1 \mathrm{kbar}$ and $1200^{\circ} \mathrm{C}$. Although there are not enough data to test its validity at pressures other than $1 \mathrm{~kb}$, we can only assume that such a correlation holds true up to 2 kbar.

\section{Thermodynamic model}

In this section we address the thermodynamics of $\mathrm{CO}_{2}$ solution in our basaltic melts, using essentially the same approach as Dixon et al. (1995). Recent work on $\mathrm{CO}_{2}$ solubility on a variety of silicate melts have emphasized that the anhydrous major element composition has relatively little effect on $\mathrm{CO}_{2}$ solubility up to 2 kbar (Botcharnikov et al., 2005; 2006). In contrast, it has been shown that dissolution of water may profoundly affect the $\mathrm{CO}_{2}$ solubility trends in a variety of silicate liquids (Mysen, 1976), the case being made strongly for andesitic to dacitic compositions (Jakobsson, 1997; King and Holloway, 2002; Behrens et al., 2004; Botcharnikov et al., 2005). In particular, experiments show that water presence 
enhances the solubility of $\mathrm{CO}_{2}$, leading to strong departure from Henrian behaviour, notably at high pressures $(>2 \mathrm{~kb})$, in agreement with earlier suggestion by Mysen (1976). Owing to water production upon reduction of ferric/ferrous iron, none of our melts is anhydrous, which means that we lack the benchmark needed to evaluate whether introduction of water in our basaltic melts indeed affects their $\mathrm{CO}_{2}$ solubility in the investigated pressure range. However, Behrens et al. (2009) observed a near linear relationships between dissolved $\mathrm{CO}_{2}$ and $\mathrm{XCO}_{2}$ at 2 kbar for their phonotephrite composition, suggesting small departure from Henrian behaviour at this, and presumably below it, pressure. Similarly, the work of Dixon et al. (1995) investigated pressures below $1 \mathrm{~kb}$, and noted an essentially Henrian behaviour of $\mathrm{CO}_{2}$ solubility, despite that the water content of their quenched melts was in the range $1-2 \mathrm{wt} \%$, as in our charges. Comparison with their data, obtained by equilibrating a MORB melt with an $\mathrm{CO}_{2}-\mathrm{H}_{2} \mathrm{O}$ vapour, with those of Stolper and Holloway (1988) and Jendrzejewsky et al. (1997), which were obtained under drier conditions $\left(\mathrm{H}_{2} \mathrm{O}<0.6 \mathrm{wt} \%\right)$ than ours, shows that all data sets fall on the same $\mathrm{fCO}_{2}$ vs $\mathrm{CO}_{2}{ }^{\text {melt }}$ trend. This indicates that the presence of $1-2 \mathrm{wt} \% \mathrm{H}_{2} \mathrm{O}$ does not affect significantly the systematics of $\mathrm{CO}_{2}$ solubility in basaltic melts up to an $\mathrm{fCO}_{2}=3000$ bar at least, which is the maximum $\mathrm{fCO}_{2}$ reached in our experiments, or that such an effect is not detectable with the analytical tools used to determine dissolved $\mathrm{CO}_{2}$. In contrast, the few data available at $5 \mathrm{~kb}$ for basalts equilibrated with mixed $\mathrm{H}_{2} \mathrm{O}-\mathrm{CO}_{2}$ fluids show a significant departure from linear behaviour between dissolved $\mathrm{CO}_{2}$ and $\mathrm{fCO}_{2}$ (Botcharnikov et al., 2005; Behrens et al., 2009), which has been interpreted as resulting from the depolymerising effects of $\mathrm{OH}$ - groups which enhances $\mathrm{CO}_{2}$ solubility (Mysen, 1976, see also Behrens et al. 2009).

In view of the above, we have modelled our experimental data using the same approach as Dixon et al. (1995), keeping in mind that our model is essentially calibrated on hydrous basalts with dissolved water contents up to $2 \mathrm{wt} \%$ at pressures below $3 \mathrm{~kb}$. Application of the equations derived below to wetter melts may result in overestimated pressures of fluid saturation.

The solubility of carbon dioxide in basaltic liquids can be described by the following simple reaction (e.g. Stolper and Holloway, 1988):

$$
\mathrm{CO}_{2, \mathrm{~mol}(\mathrm{v})}+\mathrm{O}^{2-}{ }_{(m)}=\mathrm{CO}_{3}^{2-}{ }_{(\mathrm{m})}
$$

where $\mathrm{O}^{2-}{ }_{(m)}$ represents any reactive oxygen species, $\mathrm{CO}_{2, \operatorname{mol}(v)}$ is the molecular carbon dioxide in the vapor phase, and $\mathrm{CO}_{3}^{2-}{ }_{(m)}$ is the carbonate groups dissolved in the melt. The equilibrium constant at $\mathrm{T}$ and $\mathrm{P}$ is equal to: 


$$
K(P, T)=\frac{a_{\mathrm{CO}_{3}^{2-}}^{m}(P, T)}{a_{\mathrm{O}^{2-}}^{2-} f_{\mathrm{CO}_{2}}(P, T)}
$$

Assuming that $\mathrm{O}^{2-}{ }_{(m)}$ and $\mathrm{CO}_{3}^{2-}{ }_{(m)}$ mix ideally (Stolper et al., 1997), the activity of the melt species can be substituted by their mole fractions, so that:

$$
K(P, T)=\frac{X_{\mathrm{CO}_{3}^{2-}}^{m}(P, T)}{X_{O^{2-}}^{m} * f_{\mathrm{CO}_{2}}(P, T)}
$$

Then, standard thermodynamic manipulations (e.g., Holloway and Blank, 1994) show that the pressure and temperature effects on $\mathrm{K}$ are given by:

$$
K(P, T)=K_{0}\left(P_{0}, T_{0}\right) \times \exp \left\{-\int_{P_{0}}^{P} \frac{\Delta V_{r}^{0, m}}{R T} d P+\int_{T_{0}}^{T} \frac{\Delta H_{\mathrm{H}_{2} \mathrm{O}}^{0}\left(T, P_{0}\right)}{R T ?} d T\right\}
$$

where $K_{0}\left(P_{0}, T_{0}\right)$ is the equilibrium constant at $\mathrm{P}_{0}=1000$ bar and $\mathrm{T}_{0}=1200^{\circ} \mathrm{C}$ the reference pressure and temperature, $\Delta V_{r}^{0, m}$ is the volume change of the condensed components of reaction 15: $\quad \Delta V_{r}^{o, m}=\left(V_{\mathrm{CO}_{3}^{2-}}^{o, m}\right)-\left(V_{O^{2-}}^{o, m}\right)$

where $\left(V_{\mathrm{CO}_{3}^{2-}}^{o, m}\right)$ and $\left(V_{\mathrm{O}^{2-}}^{o, m}\right)$ are the molar volume of species of the melt in their standard states. $\Delta \mathrm{H}_{\mathrm{H}_{2} \mathrm{O}}^{0}$ is the heat of solution of a mole of $\mathrm{CO}_{2}$ into the melt. Since we did not investigate specifically the temperature effect, an appropriate value of $\Delta H_{\mathrm{H}_{2} \mathrm{O}}^{0}(-13.1 \mathrm{~kJ} / \mathrm{mol})$ is that of basanite which has a composition intermediate between tholeiitic basalt and nephelinite (Holloway and Blank, 1994).

According to reaction 24, a plot of $\ln \left\{\frac{f_{\mathrm{CO}_{2}}^{0}}{X_{\mathrm{CO}_{2, \text { tot }}}}\right\}$ versus $\frac{\left(P-P_{0}\right)}{R T}$ obtained from $\mathrm{CO}_{2}$ solubility data of experiments at constant temperature, results in a straight line whose slope gives $\Delta V_{r}^{o, m}$ ( $X_{\mathrm{CO}_{2, \text { tot }}}$ is the mole fraction of total $\mathrm{CO}_{2}$ contents dissolved in the melt; figure 7).

Values calculated for VES-9, PST-9 and ETN-1 are similar to values found in previous works (Table 4): from $21.5 \mathrm{~cm}^{3} / \mathrm{mol}$ for leucitite (Thibault and Holloway, 1994), to $28 \mathrm{~cm}^{3} / \mathrm{mol}$ for tholeiite (Stolper and Holloway, 1988). There is no clear dependence between $\Delta V_{r}^{o, m}$ and the $\Pi$ parameter, however. Considering the assumptions and uncertainties associated to the determination of $\Delta V_{r}^{o, m}$ with the above method we can only say that in most basaltic liquids $\Delta V_{r}^{o, m}$ is close to $25 \pm 3 \mathrm{~cm}^{3} / \mathrm{mol}$. It is also important to note that the values of $\Delta V_{r}^{o, m}$ 
calculated here are for moderately hydrous basalts only and should not be interpreted as an accurate measurement of $\Delta V_{r}^{o, m}$ (e.g., Zhang,1999).

Then, knowing values of $\Delta V_{r}^{o, m}$, values of $\ln \mathrm{K}_{0}$ can be calculated. Values found are similar to those calculated in previous works (Table 4). The influence of melt composition on the solubility of $\mathrm{CO}_{2}$ is borne out by the variability of $\mathrm{K}^{\circ}$ constants determined in this and other studies (Holloway and Blank, 1994). A plot of $\ln K^{\circ}$ versus $\Pi$ (Fig. 8) reveals that there exists a good linear relationship between these two parameters.

Linear regression of the data set yields the following equation:

$$
\ln \mathrm{K}^{\circ}=0.893 \Pi-15.247
$$

with a correlation coefficient $\mathrm{R}^{2}=0.891$.

The above parameterisation of the $\mathrm{K}^{\circ}$ coefficient offers a simple model of calculating the solubility of $\mathrm{CO}_{2}$ in basaltic melts with varying alkali contents. The results of back calculations of the $\mathrm{CO}_{2}$ contents of our experimental quenched glasses performed with this model are shown against measured $\mathrm{CO}_{2}$ values (Fig. 9). The model appears to retrieve observed $\mathrm{CO}_{2}$ contents to within $10 \%$ relative.

\section{Application to the calculation of saturation pressures for alkali-rich basaltic compositions}

Having determined solubility the laws of $\mathrm{H}_{2} \mathrm{O}$ (Lesne et al., this issue) and $\mathrm{CO}_{2}$ in the three basaltic melts from Vesuvius, Etna and Stromboli, we are now able to calculate saturation pressures of melt inclusions analysed in related volcanic products. By determining the total water and $\mathrm{CO}_{2}$ dissolved in the melt inclusions, we are able to calculate fugacities and partial pressures of those species, and then the saturation pressures at which volatiles were entrapped in the melt inclusion (ignoring the role of other volatiles, in particular sulphur and halogens).

For Vesuvius, we use the data of Marianelli et al. $(1999,2005)$ and Fulignati et al. (2004) to calculate saturation pressures. In those previous works, the quantities of dissolved water and carbon dioxide were determined via FTIR measurements. They considered the $\mathrm{OH}$ stretching vibration band at $3535 \mathrm{~cm}-1$ for measuring the water content, which was not used for measuring water content in our experimental glasses. $\mathrm{CO}_{2}$ contents were calculated using the Dixon and Pan (1995) relationship (Marianelli et al., 2005) and using $\varepsilon_{1515}=365$ l.mol1.cm-1 (Fulignati et al., 2004) and $\varepsilon_{1515}=380$ 1.mol-1.cm-1 (Cioni, 2000). Those values of $\varepsilon_{1515}$ are not so different from that of Fine and Stolper (1986) used in this study, and translate into a maximum difference of $3 \%$ on the total carbon dissolved in the melt. Such a difference in $\mathrm{CO}_{2}$ content will not induce a significant effect on the saturation pressures calculated. Both 
Marianelli et al. (1999, 2005) and Fulignati et al. (2004) used VolatileCalc to calculate saturation pressures. Comparison of their findings with our own model shows that previous calculated pressures were overestimated by $50 \%$ on average (figure $10 \mathrm{a}$ ).

For Etna we use the recent data of Métrich et al. (2004) and Spilliaert et al. (2006) who calculated saturation pressures with the VolatileCalc model (Newman and Lowenstern, 2002). To determine the $\mathrm{CO}_{2}$ content of melt inclusions, Spilliaert et al. (2006) used a LPS nuclear microprobe, whilst for water they used a CAMECA IMS3f ion microprobe. Métrich et al. (2004) determined, instead, water and carbon contents by using the FTIR technique. As for Vesuvius, Métrich et al. (2004) determined water contents by using the total water band assignment and determined $\mathrm{CO}_{2}$ content by using the molar extinction coefficient calculated from the Dixon and Pan (1995) relationship. Thus, $\mathrm{CO}_{2}$ contents in melt inclusions and in our glasses are comparable, whereas the method used to calculate water content is not the same which could induce some differences in calculated water fugacities. Our calculated range of saturation pressures varies from 200 to 4200 bars, which is broadly similar to the range of pressures calculated by Métrich et al. (2004) and Spilliaert et al. (2006) (figure 10b).

For Stromboli, we refer to the data of Métrich et al. (2001) and Bertagnini et al. (2003) who calculated saturation pressures of melt inclusions by using Papale's (1999) model. Both determined water and total carbon contents in the melt inclusions by using FTIR and the relationship of Dixon and Pan (1995) to determine $\varepsilon_{1515}$. Métrich et al. (2001) used extinction coefficient values for the 5200 and $4500 \mathrm{~cm}-1$ band assignments of Dixon et al. (1995), whereas Bertagnini et al. (2003) used the $3535 \mathrm{~cm}-1$ band assignment. Thus, the data of Métrich et al. (2001) are directly comparable to ours, contrary to the water contents of Bertagnini et al. (2003). However, as $\mathrm{CO}_{2}$ largely predominates over $\mathrm{H}_{2} \mathrm{O}$ when calculating saturation pressures, comparison between our calculations and those of previous works can still be done faithfully. Métrich et al. (2001) and Bertagnini et al. (2003) found a range of saturation pressures from 2800 up to more than 4000 bars, with a cluster at 3500 bars. Both studies do not tabulate the calculated pressures, which prevents us from drawing a comparative plot such as done for Vesuvius and Etna. Our results yield a range of saturation pressures from 1500 to 3000 bars, with a cluster at 2500 bars, which is 1000 bars less than the cluster found by Bertagnini et al. (2003).

It thus appears that VolatileCalc overestimates the saturation pressures by $70 \%$ for Vesuvius basalt, by $26 \%$ for Stromboli and by $14 \%$ for Etnean basalt. Botcharnikov et al (2005) have already shown that VolatileCalc does not work properly at pressures significantly higher than $2 \mathrm{~kb}$, tending also to overestimate fluid saturation pressures for common basalt- 
andesite-rhyolite melts. The present study shows that a further limitation of this model is its failure in correctly predicting saturation pressures for alkali-rich mafic melts. A similar conclusion was reached by Behrens et al. (2009). For those melts, it appears that more complex models, such as that of Papale (1999), are needed to better account for the possible interactions between $\mathrm{H}_{2} \mathrm{O}$ and $\mathrm{CO}_{2}$ in silicate melts (see for instance Tamic et al., 2001), in addition to other compositional effects.

\section{Conclusions}

Experiments at $1200^{\circ} \mathrm{C}$ and pressures from 250 to 2086 bar have been performed to determine the solubilities of $\mathrm{CO}_{2}$ in alkali basaltic melts.

1. Results of $\mathrm{CO}_{2}$ contents presented in this study were measured by infrared measurements. Without any bulk carbon data, we used the molar extinction coefficient given by Fine and Stolper (1986) for basaltic melts, as well as molar extinction coefficients calculated from the melt composition given by Dixon and Pan (1995). Clearly, there is still a large uncertainty surrounding the determination of extinction coefficients in basaltic glasses and their variations with alkali and alkali-earth elements, which considerably hamper an accurate determination of dissolved $\mathrm{CO}_{2}$ in basalts other than MORBs. Future work should be directed at a better definition of such a relationships

2. Aside from this problem, our experiments, along with previous similar works, show that the solubility of any particular melt can be modelled in a simple way. For the three worked compositions, such simple relationships are:

$$
\begin{array}{ll}
f_{\mathrm{CO}_{2}}^{120{ }^{\circ} \mathrm{C}}=8.57 * 10^{6} * X_{\mathrm{CO}_{2}}^{m} ; & \mathrm{R}^{2}=0.99 \text { for Vesuvius } \\
f_{\mathrm{CO}_{2}}^{1200^{\circ} \mathrm{C}}=1.14 * 10^{7} * X_{\mathrm{CO}_{2}}^{m}{ }^{1.23} ; & \mathrm{R}^{2}=0.93 \text { for Etna } \\
f_{\mathrm{CO}_{2}}^{120{ }^{\circ} \mathrm{C}}=3.49 * 10^{6} * X_{\mathrm{CO}_{2}}^{m} ; & \mathrm{R}^{2}=0.99 \text { for Stromboli }
\end{array}
$$

3. Experimental results obtained on these basaltic compositions show a strong effect of alkalis on $\mathrm{CO}_{2}$ behaviour in these melts, confirming previous studies (Dixon, 1997; Behrens et al., 2009): at any pressure of the investigated range, alkali-rich basalts dissolve up to 1.7 times more $\mathrm{CO}_{2}$ than alkali-poor basalts, and up to 2 times more than a MORB. 
4. Data obtained in this study provide a refinement of the model of Dixon (1997): the parameterisation between the $\mathrm{CO}_{2}$ solubility at $1 \mathrm{kbar}$ and $1200^{\circ} \mathrm{C}$ and the $\Pi$ factor is confirmed, and the extended data base yields: $\mathrm{CO}_{2}(\mathrm{ppm})=920( \pm 1) \Pi-17( \pm 53)$,

5. Comparing our data with those obtained in previous works, it appears that there exists a compositional dependence for $\ln K^{\circ}$, which varies linearly with the $\Pi$ parameter, therefore providing a basis for a simple thermodynamical modelling of $\mathrm{CO}_{2}$ solubility in basaltic melts.

6. Lastly, application of our results to the calculation of volatile saturation pressures using dissolved $\mathrm{H}_{2} \mathrm{O}$ and $\mathrm{CO}_{2}$ contents of primitive melt inclusions from the three studied volcanoes shows that previous saturation pressures of primitive magmas feeding these volcanoes were significantly overstimated, notably for the Vesuvius.

\section{Acknowledgements:}

We thank reviewers $\mathrm{A}$ and $\mathrm{B}$ for helpful reviews. This paper is part of the $\mathrm{PhD}$ thesis of the senior author. It has been partly financially supported by INGV funds and by the department of the Italian Civil Defence. 


\section{References}

Behrens H, Ohlhorst S, Holtz F, Champenois M (2004) CO2 solubility in dacitic melts equilibrated with $\mathrm{H}_{2} \mathrm{O}-\mathrm{CO}_{2}$ fluids: Implications for modelling the solubility of $\mathrm{CO}_{2}$ in silicic melts. Geochimica et Cosmochimica Acta 68: 4687-4703

Behrens H, Misiti V, Freda C, Vetere F, Botcharnikov RE and Scarlato P (2009) Solubility of $\mathrm{H}_{2} \mathrm{O}$ and $\mathrm{CO}_{2}$ in ultrapotassic melts at 1200 and 1250 degrees $\mathrm{C}$ and pressure from 50 to $500 \mathrm{MPa}$. American Mineralogist 94:105 -120

Berndt J, Liebske C, Holtz F, Freise M, Nowak M, Ziegenbein D, Hurkuck W, Koepke J (2002) A combined rapid-quench and H-2-membrane setup for internally heated pressure vessels: Description and application for water solubility in basaltic melts. American Mineralogist 87:1717-1726

Bertagnini A, Metrich N, Landi P, Rosi M (2003) Stromboli volcano (Aeolian Archipelago, Italy): An open window on the deep-feeding system of a steady state basaltic volcano. Journal of Geophysical Research-Solid Earth 108(B7) doi:10.1029/2002JB002146

Blank JG, Stolper EM, Carroll MR (1993) Solubilities of carbon-dioxide and water in rhyolitic melt at 850 degrees $\mathrm{C}$ and 750 bars. Earth and Planetary Science Letters $119(1-2): 27-36$

Blank JG, Brooker RA (1994) Experimental studies of carbon-dioxide in silicate melts. Solubility, speciation, and stable carbon-isotope behaviour. In: Volatiles in Magmas, vol 30. Mineralogical Soc America, Washington, pp 157-186

Botcharnikov R, Freise M, Holtz F, Behrens H (2005) Solubility of C-O-H mixtures in natural melts: new experimental data and application range of recent models. Annals of Geophysics 48:633-646

Botcharnikov RE, Behrens H, Holtz F (2006) Solubility and speciation of C-O-H fluids in andesitic melt at $\mathrm{T}=1100-1300$ degrees $\mathrm{C}$ and $\mathrm{P}=200$ and $500 \mathrm{MPa}$. Chemical Geology 229: 125-143

Bourgue E, Richet P (2001) The effects of dissolved $\mathrm{CO}_{2}$ on the density and viscosity of silicate melts: a preliminary study. Earth and Planetary Science Letters 193(1-2): 5768

Burgisser A, Scaillet B (2007) Redox evolution of a degassing magma rising to the surface. Nature 445(7124): 194-197

Cioni R (2000) Volatile content and degassing processes in the AD 79 magma chamber at Vesuvius (Italy). Contributions to Mineralogy and Petrology 140(1): 40-54

Di Carlo I, Pichavant M, Rotolo SG, Scaillet B (2006) Experimental crystallization of a high$\mathrm{K}$ arc basalt: The golden pumice, Stromboli volcano (Italy). Journal of Petrology 47(7): 1317-1343 
Dixon JE, Pan V (1995) Determination of the molar absorptivity of dissolved carbonate in basanitic glass. American Mineralogist 80: 1339-1342

Dixon JE, Stolper EM, Holloway JR (1995) An experimental study of water and carbon dioxide solubilities in mid ocean ridge basaltic liquids .1. Calibration and solubility models. Journal of Petrology 36: 1607-1631

Dixon JE (1997) Degassing of alkalic basalts. American Mineralogist 82: 368-378

Ferry JM and Baumgartner L (1987) Thermodynamic models of molecular fluids at the elevated pressures and temperatures of crustal metamorphism (1987) Reviews in Mineralogy 17: 323-365

Fine G, Stolper E (1985) The speciation of carbon-dioxide in sodium aluminosilicate glasses. Contributions to Mineralogy and Petrology 91(2): 105-121

Fine G, Stolper E (1986) Dissolved carbon-dioxide in basaltic glasses. Concentrations and speciation. Earth and Planetary Science Letters 76(3-4): 263-278

Fulignati P, Marianelli P, Metrich N, Santacroce R, Sbrana A (2004) Towards a reconstruction of the magmatic feeding system of the 1944 eruption of Mt Vesuvius. Journal of Volcanology and Geothermal Research 133(1-4): 13-22

Holloway JR, Blank JG (1994) Application of experimental results to C-O-H species in natural melts. In: Volatiles in Magmas, vol 30. Mineralogical Soc America, Washington, pp 187-230

Holloway JR, Pan V, Gudmundsson G, Hb (1992) High-pressure fluid-absent melting experiments in the presence of graphite: oxygen fugacity, ferric/ferrous ration and dissolved $\mathrm{CO}_{2}$. European Journal of Mineralogy 4: 105-114

Holloway JR (1987) Igneous fluids. Reviews in Mineralogy 17: 211-233

Holloway JR (1977) Fugacity and activity of molecular species in supercritical fluids. Thermodynamics in Geology: 161-181

Jakobsson S (1997) Solubility of water and carbon dioxide in an icelandite at 1400 degrees C and 10 kilobars. Contributions To Mineralogy And Petrology 127: 129-135

Jendrzejewski N, Trull TW, Pineau F, Javoy M, Xa (1997) Carbon solubility in Mid-Ocean Ridge basaltic melt at low pressures (250-1950 bar). Chemical Geology 138(1-2): $81-92$

King PL, Holloway JR (2002) $\mathrm{CO}_{2}$ solubility and speciation in intermediate (andesitic) melts: The role of $\mathrm{H}_{2} \mathrm{O}$ and composition. Geochimica Et Cosmochimica Acta 66: 16271640

Lange RA (1994) The effect of $\mathrm{H}_{2} \mathrm{O}, \mathrm{CO}_{2}$ and $\mathrm{F}$ on the density and viscosity of silicate melts. In: Volatiles in Magmas, vol 30. Mineralogical Soc America, Washington, pp 331369 
Lesne P, Scaillet B, Pichavant M, Iacono-Marziano G, Beny JM (in prep.) The $\mathrm{H}_{2} \mathrm{O}$ solubility of alkali basalts: an experimental study

Marianelli P, Metrich N, Santacroce R, Sbrana A (1995) Mafic magma batches at Vesuvius. A glass inclusion approach to the modalities of feeding stratovolcanoes. Contributions to Mineralogy and Petrology 120(2): 159-169

Marianelli P, Metrich N, Sbrana A (1999) Shallow and deep reservoirs involved in magma supply of the 1944 eruption of Vesuvius. Bulletin of Volcanology 61(1-2): 48-63

Marianelli P, Sbrana A, Metrich N, Cecchetti A (2005) The deep feeding system of Vesuvius involved in recent violent strombolian eruptions. Geophysical Research Letters 32: L02306

Metrich N, Allard P, Spilliaert N, Andronico D, Burton M (2004) 2001 flank eruption of the alkali- and volatile-rich primitive basalt responsible for Mount Etna's evolution in the last three decades. Earth and Planetary Science Letters 228(1-2): 1-17

Metrich N, Bertagnini A, Landi P, Rosi M (2001) Crystallization driven by decompression and water loss at Stromboli volcano (Aeolian Islands, Italy). Journal of Petrology 42(8): 1471-1490

Morizet Y, Brooker RA, Kohn SC (2002) CO2 in haplo-phonolite Melt: Solubility, speciation and carbonate complexation. Geochimica et Cosmochimica Acta 66(10): 1809-1820

Mysen BO (1976) Experimental-determination of some geochemical parameters relating to conditions of equilibration of peridotite in upper mantle. American Mineralogist 61: 677-683

Newman S, Lowenstern JB (2002) VOLATILECALC: a silicate melt- $\mathrm{H}_{2} \mathrm{O}-\mathrm{CO}_{2}$ solution model written in Visual Basic for excel. Computers \& Geosciences 28(5): 597-604

Ohmoto H and Kerrick D (1977) Devolatilization equilibria in graphitic systems. American Journal of Science, 277: 1013-1044

Pan V, Holloway JR, Hervig RL (1991) The pressure and temperature-dependence of carbondioxide solubility in tholeiitic basalt melts. Geochimica Et Cosmochimica Acta 55(6): 1587-1595

Papale $\mathrm{P}$ (1997) Modelling of the solubility of a one-component $\mathrm{H}_{2} \mathrm{O}$ or $\mathrm{CO}_{2}$ fluid in silicate liquids. Contributions to Mineralogy and Petrology 126(3): 237-251

Papale P (1999) Strain-induced magma fragmentation in explosive eruptions. Nature 397(6718): 425-428

Papale P, Moretti R, Barbato D (2006) The compositional dependence of the saturation surface of $\mathrm{H} 2 \mathrm{O}+\mathrm{CO} 2$ fluids in silicate melts. Chemical Geology 229(1-3): 78-95 
Pawley AR, Holloway JR, McMillan PF (1992) The effect of oxygen fugacity on the solubility of carbon oxygen fluids in basaltic melt. Earth and Planetary Science Letters 110(1-4): 213-225

Pichavant M, Di Carlo I, Le Gac Y, Rotolo S, Scaillet B (2009) The deep feeding system of basaltic volcanoes: experimental evidence from Stromboli (Italy). Journal of Petrology 50: 601-624

Richet P, Whittington A, Holtz F, Behrens H, Ohlhorst S, Wilke M, (2000) Water and the density of silicate glasses. Contributions to Mineralogy and Petrology 138: 337-347

Robock A (2000) Volcanic eruptions and climate. Reviews of Geophysics 38(2): 191-219

Roux J, Lefevre A (1992) A fast-quench device for internally heated pressure-vessels. European Journal of Mineralogy 4: 279-281

Silver L, Stolper E (1985) A thermodynamical model for hydrous silicate melts. Journal of Geology 93: 161-177

Spilliaert N, Allard P, Metrich N, Sobolev AV (2006a) Melt inclusion record of the conditions of ascent, degassing, and extrusion of volatile-rich alkali basalt during the powerful 2002 flank eruption of Mount Etna (Italy). Journal of Geophysical Research-Solid Earth 111: B04203

Spilliaert N, Metrich N, Allard P (2006b) S-Cl-F degassing pattern of water-rich alkali basalt: Modelling and relationship with eruption styles on Mount Etna volcano. Earth and Planetary Science Letters 248(3-4): 772-786

Stolper E, Fine G, Johnson T, Newman S (1987) Solubility of carbon-dioxide in albitic melt. American Mineralogist 72: 1071-1085

Stolper E, Holloway JR (1988) Experimental determination of the solubility of carbondioxide in molten basalt at low-pressure. Earth and Planetary Science Letters 87(4): $397-408$

Thibault Y, Holloway JR, Na (1994) Solubility of $\mathrm{CO}_{2}$ in a Ca-rich leucitite. Effects of pressure, temperature, and oxygen fugacity. Contributions to Mineralogy and Petrology 116(1-2): 216-224

Zhang $\mathrm{Y}$ (1999) $\mathrm{H}_{2} \mathrm{O}$ in rhyolitic glasses and melts: Measurement, speciation, solubility, and diffusion. Reviews of Geophysics, 37: 493-516 


\section{FIGURE CAPTIONS}
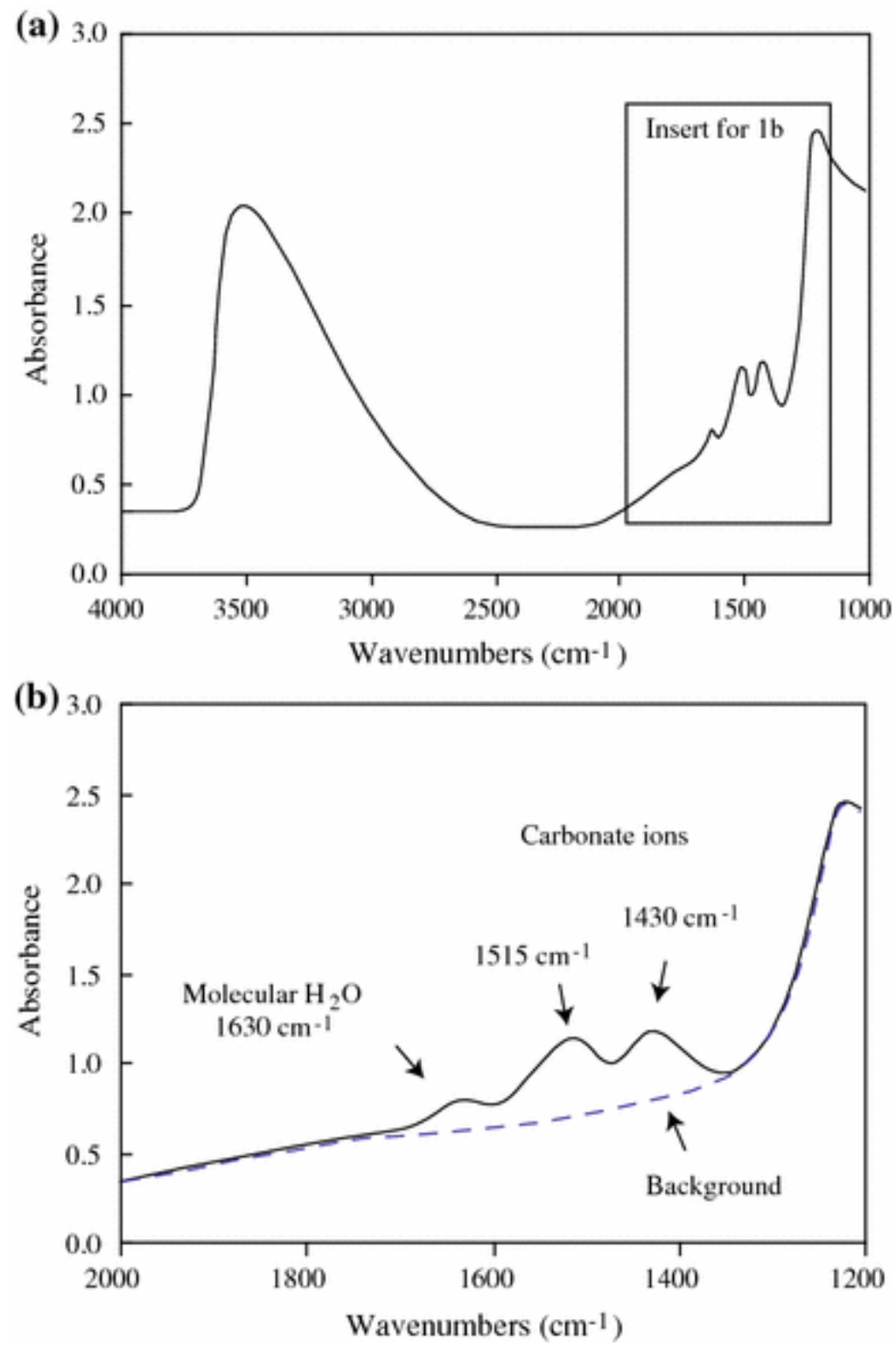

Figure 1:

Typical mid-IR spectrum of basaltic glass from experiment run1\#4 (ETN-1) (thickness $133 \mu \mathrm{m})$ showing the absorptions of carbonate bands $(1515 \mathrm{~cm}-1$ and $1430 \mathrm{~cm}-1)$. Small peaks at $2350 \mathrm{~cm}-$ 1 are absorptions by atmospheric $\mathrm{CO}_{2}$. Background modelled as described in text. 


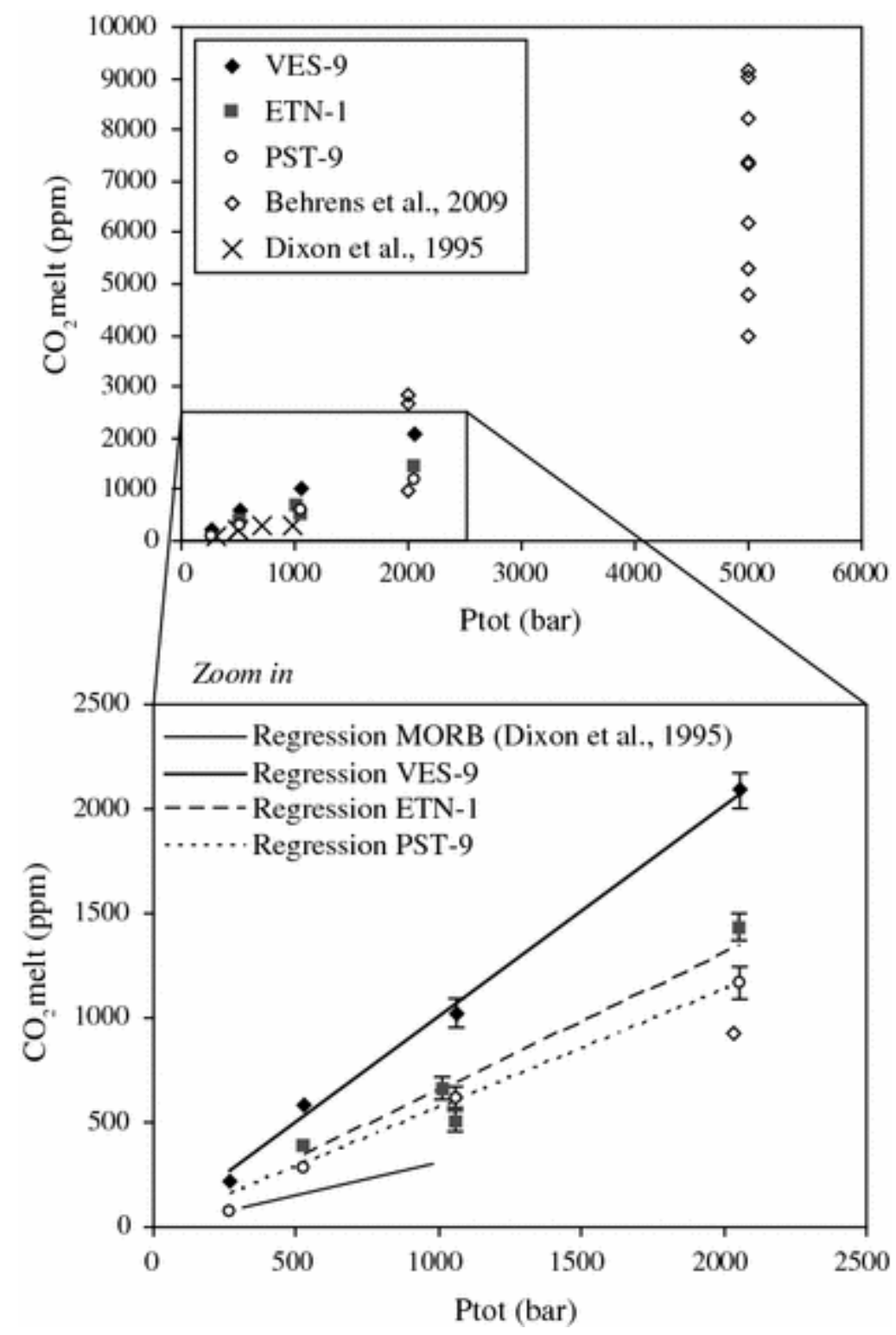

Figure2:

Experimental results on $\mathrm{CO}_{2}$ contents in basaltic melts (Vesuvius, Etna, Stromboli and MORB from Dixon et al., 1995), versus experimental pressure. 


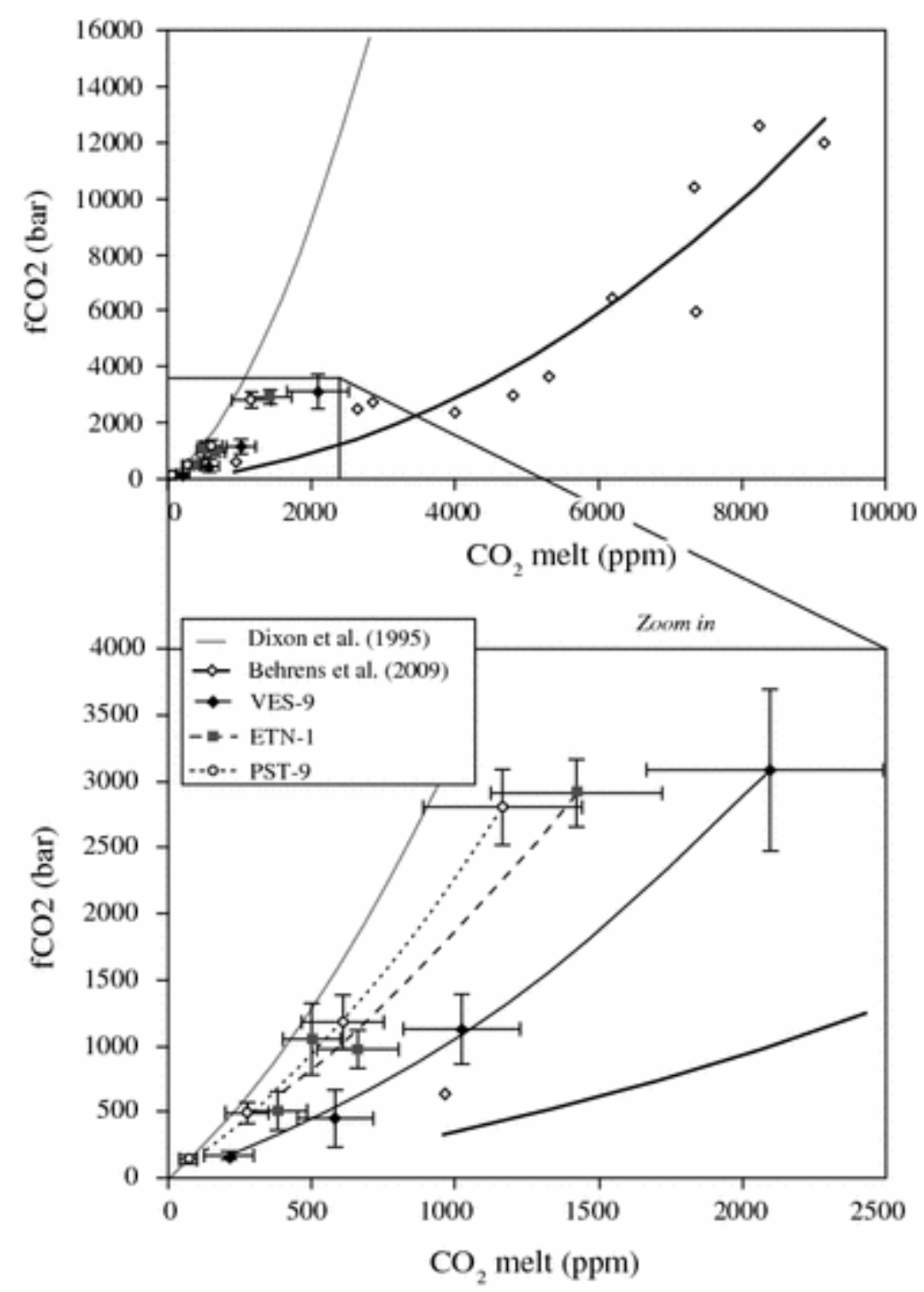

Figure 3:

Fugacity of $\mathrm{CO}_{2}$ for VES-9, ETN-1 and PST-9, calculated with an MRK equation of state (Holloway, 1977), versus $\mathrm{CO}_{2}$ dissolved in the melts in ppm. Model from Dixon et al. (1995) obtained on MORB are reported. Errors on $\mathrm{f}_{\mathrm{CO} 2}$ are smaller than the symbols. 


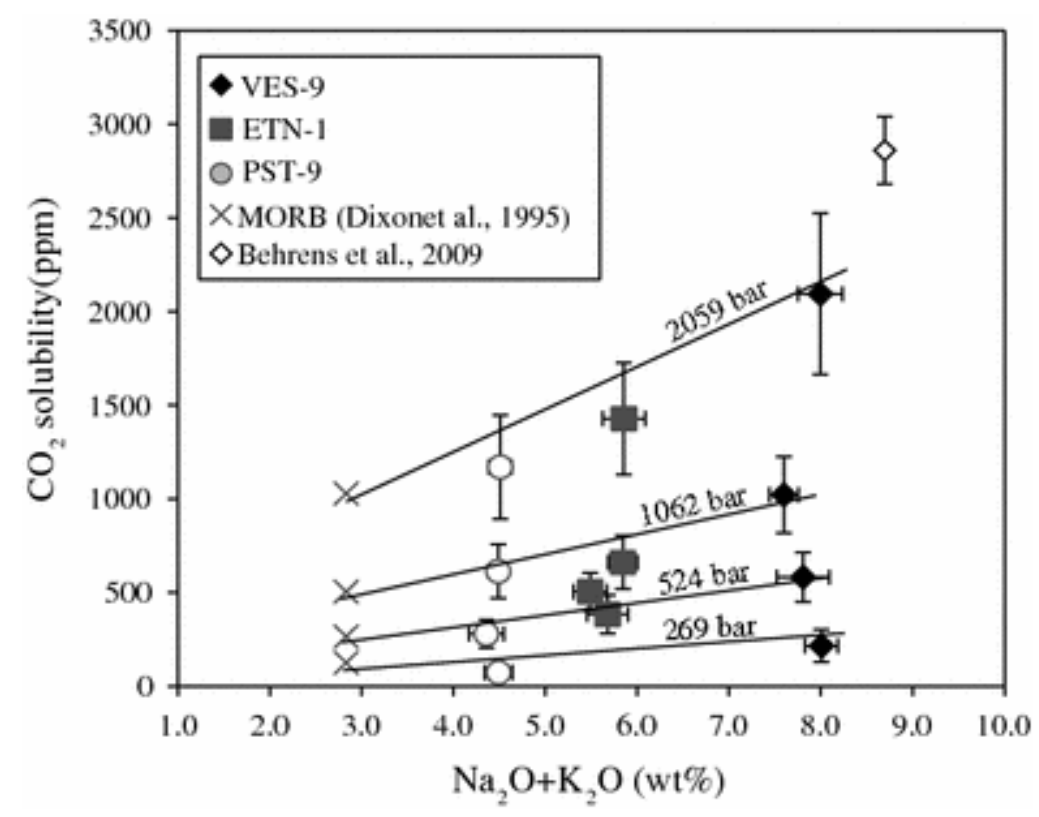

Figure 4:

$\mathrm{CO}_{2}$ solubility calculated at experimental pressures in basaltic melts against the alkalinity of the melt.

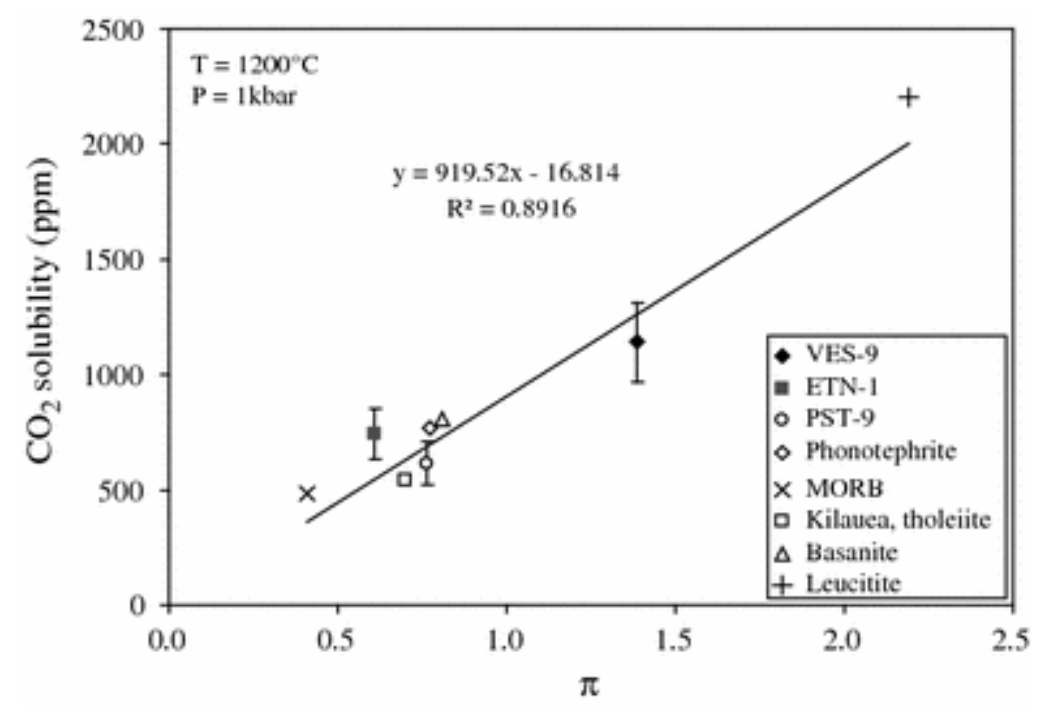

Figure 5:

Saturation pressures calculated with VolatileCalc (Newmann and Lowenstern, 2002) for VES-9, ETN-1, PST-9, taking total $\mathrm{SiO}_{2}$ measured in hydrous glass, at $\mathrm{T}=1200^{\circ} \mathrm{C}$, versus experimental pressures. Calculated saturation pressures of MORB (Dixon et al., 1995) were calculated and reported (crosses). 


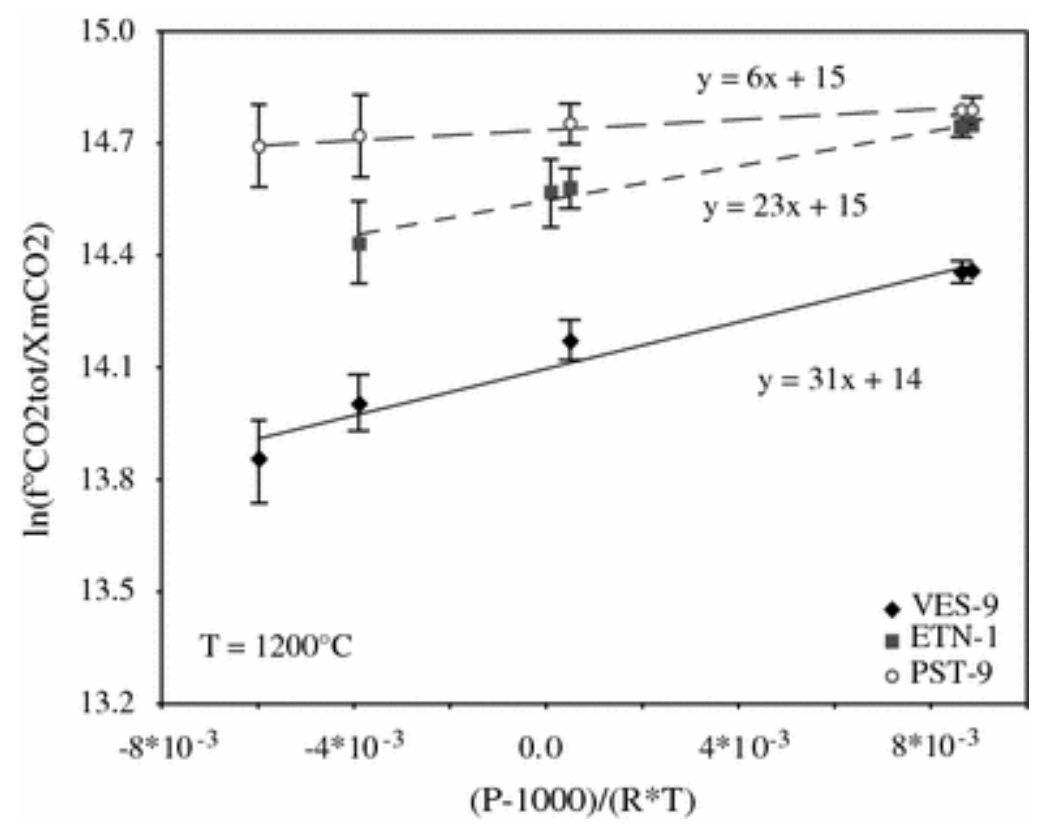

Figure 6:

$\mathrm{CO}_{2}$ (ppm) solubility calculated for Vesuvius, Etna and Stromboli at $1200^{\circ} \mathrm{C}$ and $1 \mathrm{kbar}$, using solubility laws defined in this study, against the $\Pi$ factor defined by Dixon (1997).

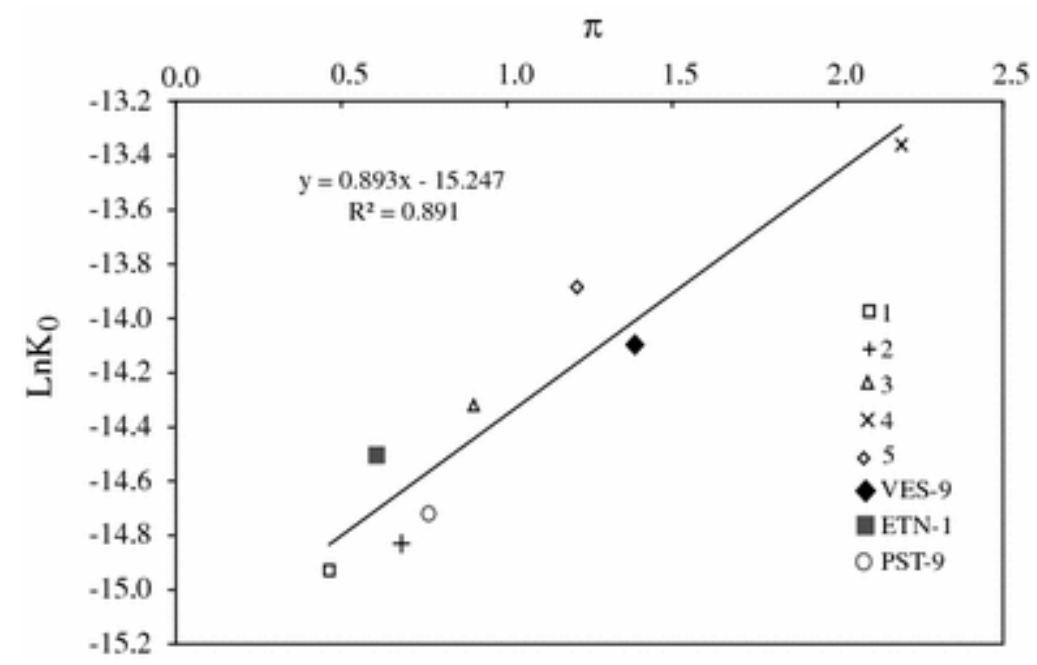

Figure 7:

Determination of $\Delta V_{r}^{o, m}$ by fitting $\ln \left\{\frac{f_{\mathrm{CO}_{2}}^{0}}{X_{\mathrm{CO}_{2, \text { tot }}}}\right\}$ versus $\frac{\left(P-P_{0}\right)}{R T}$. 


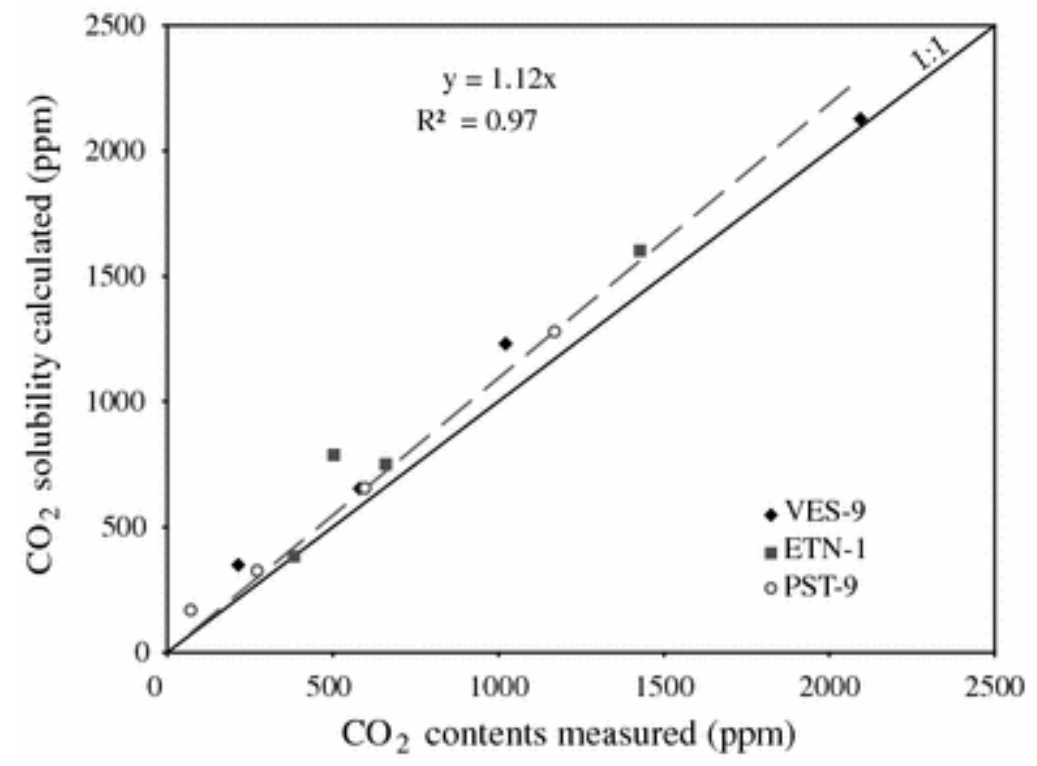

Figure 8:

$\mathrm{LnK}^{\circ}$ versus $\Pi$ parameter (Dixon 1997). 

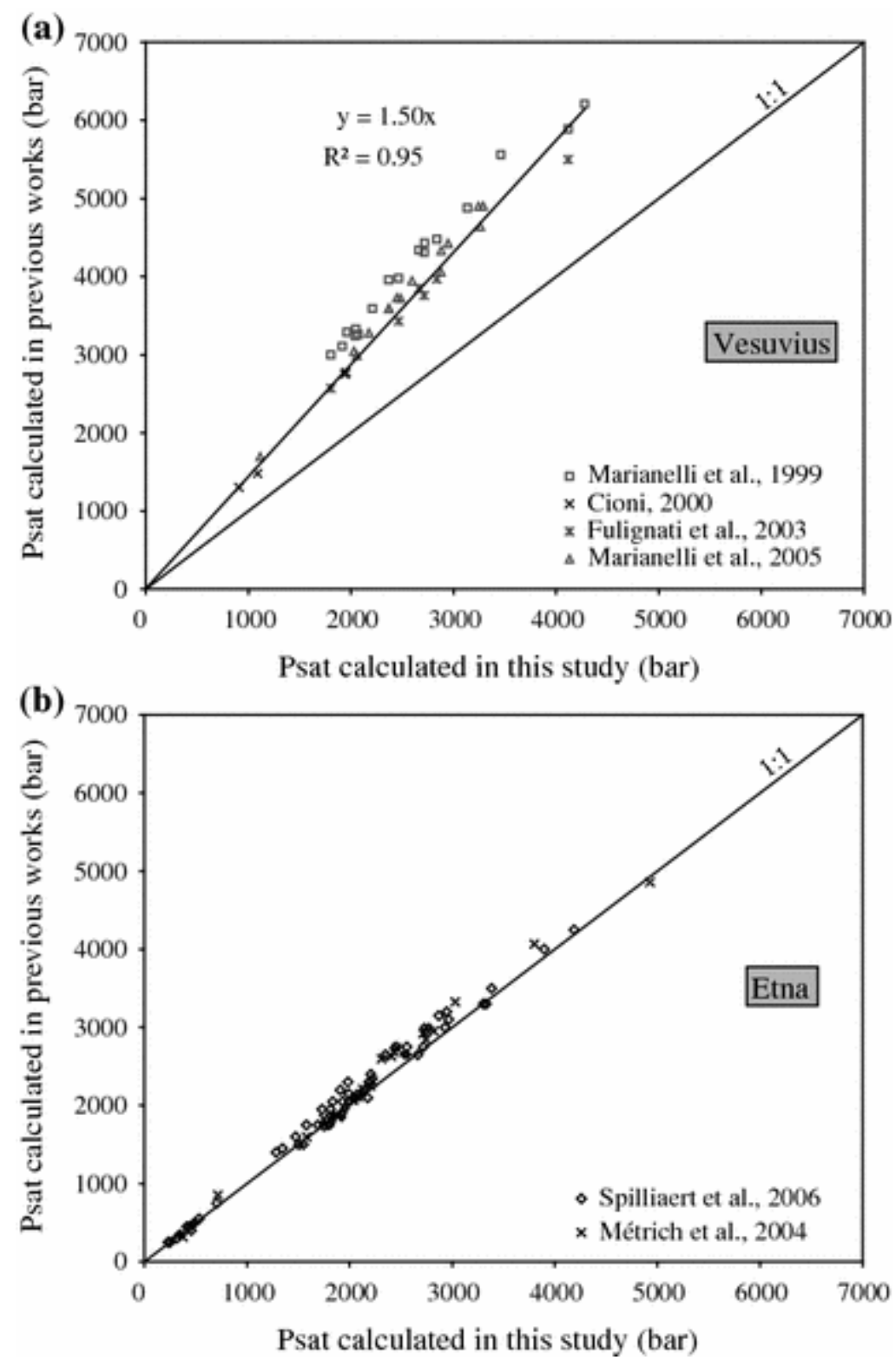

Figure 9:

Comparison between measured and calculated $\mathrm{CO}_{2}$ content with the thermodynamical parameters calculated in this study. 

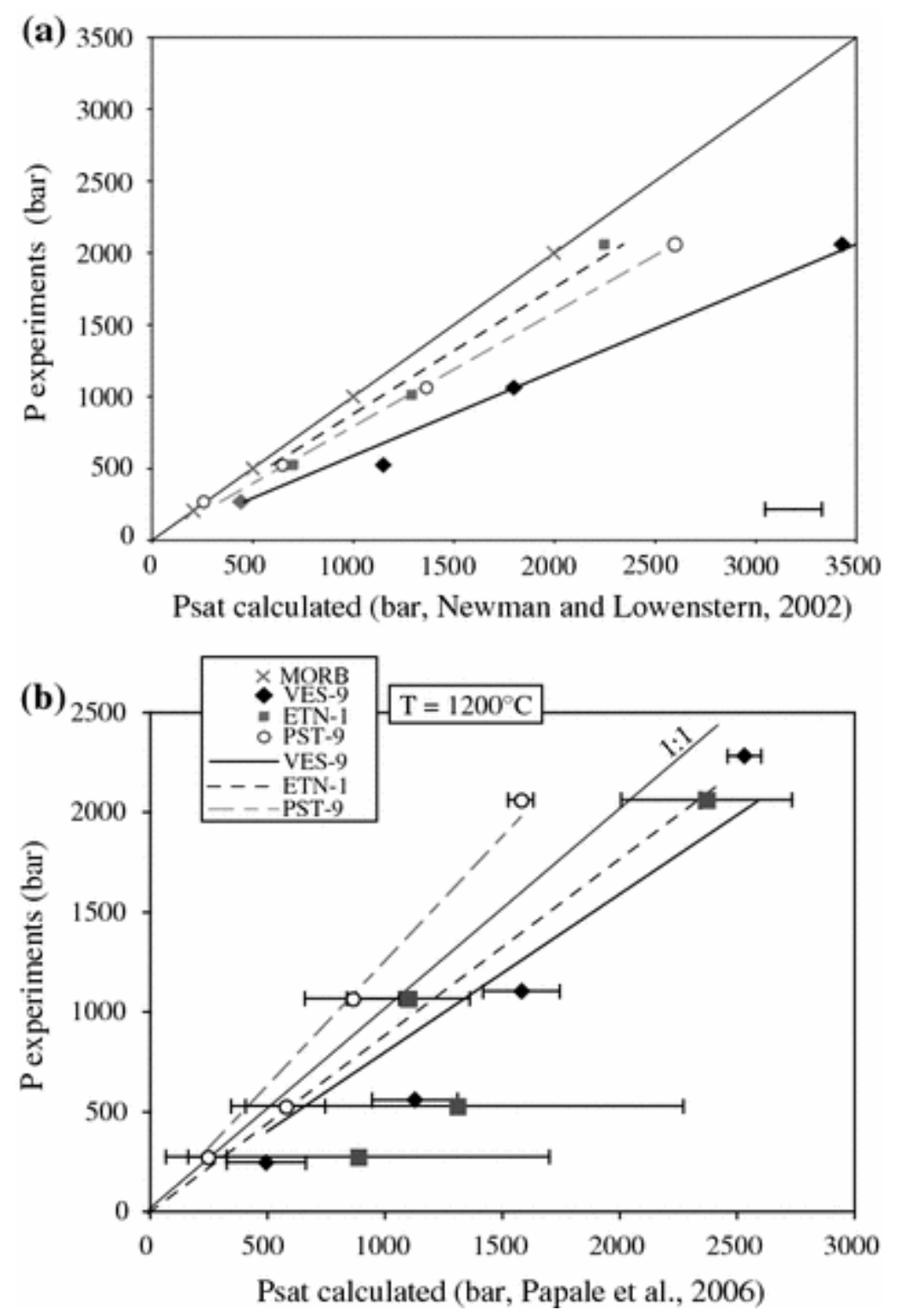

Figure 10:

Saturation pressures calculated by using data from melt inclusions of (a) Vesuvian products from Marianelli et al (1999), Cioni (2000), Fulignati et al. (2004) and Marianelli (2005) and of (b) Etnean products Métrich et al. (2004) and Spilliaert et al. (2006), compared to the saturation pressures calculated by using our solubility laws. 
Tables

Table 1 Bulk rock compositions

\begin{tabular}{|c|c|c|c|}
\hline Oxides & VES-9 $^{a}$ & ETN-1 $^{b}$ & PST-9 $^{c}$ \\
\hline $\mathrm{SiO}_{2}$ & 48.67 & 47.95 & 49.82 \\
\hline $\mathrm{TiO}_{2}$ & 0.97 & 1.67 & 0.81 \\
\hline $\mathrm{Al}_{2} \mathrm{O}_{3}$ & 14.72 & 17.32 & 15.94 \\
\hline $\mathrm{FeO}$ & 7.62 & 10.24 & 7.71 \\
\hline $\mathrm{MnO}$ & 0.14 & 0.17 & 0.20 \\
\hline $\mathrm{MgO}$ & 6.82 & 5.76 & 8.07 \\
\hline $\mathrm{CaO}$ & 12.94 & 10.93 & 12.81 \\
\hline $\mathrm{Na}_{2} \mathrm{O}$ & 1.82 & 3.45 & 2.32 \\
\hline $\mathrm{K}_{2} \mathrm{O}$ & 5.63 & 1.99 & 1.92 \\
\hline $\mathrm{P}_{2} \mathrm{O}_{5}$ & 0.66 & 0.51 & 0.40 \\
\hline Total & 100.00 & 100.00 & 100.00 \\
\hline
\end{tabular}


Table 2 Experimental conditions and FTIR results for $\mathrm{H}_{2} \mathrm{O}$ and $\mathrm{CO}_{2}$ dissolved in experimental glasses

\begin{tabular}{|c|c|c|c|c|c|c|c|c|}
\hline Run & $\begin{array}{l}\text { Compositio } \\
\text { n }\end{array}$ & $\begin{array}{l}\text { Capsul } \\
\text { e }\end{array}$ & $\begin{array}{l}\text { wt } \% \\
\mathrm{H}_{2} \mathrm{O} \\
\text { loade } \\
\text { d }\end{array}$ & $\begin{array}{l}\text { wt\% } \\
\mathrm{CO}_{2} \\
\text { loade } \\
\text { d }\end{array}$ & $\begin{array}{l}\% \\
\text { FeO } \\
\text { kept } \\
\text { a }\end{array}$ & $\begin{array}{l}\text { wt\% } \\
\mathrm{H}_{2} \mathrm{O}_{\text {tot }}\end{array}$ & $\begin{array}{l}\mathrm{CO}_{2}{ }^{\mathrm{c}} \\
(\mathrm{ppm})\end{array}$ & $\begin{array}{l}\mathrm{CO}_{2}{ }^{d} \\
(\mathrm{ppm})\end{array}$ \\
\hline
\end{tabular}

Experiment 1: 2,059 bars, duration: $4 \mathrm{~h}$

\begin{tabular}{|l|l|l|l|l|l|l|l|l|l|}
\hline Run1\#2 & VES-9 & Pt & 0 & 3.93 & 68 & $\begin{array}{l}0.80 \pm 0.4 \\
0\end{array}$ & $\begin{array}{l}2,094 \pm 43 \\
1\end{array}$ & $\begin{array}{l}2,061 \pm 43 \\
1\end{array}$ \\
\hline Run1\#4 & ETN-1 & Pt & 0 & 4.15 & 79 & $\begin{array}{l}1.49 \pm 0.1 \\
3\end{array}$ & $\begin{array}{l}1,429 \pm 29 \\
9\end{array}$ & $\begin{array}{l}1,638 \pm 29 \\
9\end{array}$ \\
\hline Run1\#6 & PST-9 & Pt & 0 & 4.35 & 70 & $\begin{array}{l}1.58 \pm 0.1 \\
6\end{array}$ & $\begin{array}{l}1,170 \pm 27 \\
7\end{array}$ & $\begin{array}{l}1,196 \pm 27 \\
7\end{array}$ \\
\hline
\end{tabular}

Experiment 2: 1,013 bars, duration: $8 \mathrm{~h}$

\begin{tabular}{|l|l|l|l|l|l|l|l|l|}
\hline Run2\#8 & ETN-1 & Pt & 0 & 1.91 & 70 & $1.55 \pm 0.2$ & $661 \pm 142$ & $757 \pm 142$ \\
\hline
\end{tabular}

Experiment 3: 524 bars, duration: $4 \mathrm{~h}$

\begin{tabular}{|l|l|l|l|l|l|l|l|l|}
\hline Run3\#4 & VES-9 & Pt & 0 & 3.93 & 83 & $\begin{array}{l}0.82 \pm 0.3 \\
7\end{array}$ & $582 \pm 132$ & $572 \pm 132$ \\
\hline Run3\#5 & ETN-1 & Pt & 0 & 3.94 & 83 & $\begin{array}{l}0.73 \pm 0.2 \\
0\end{array}$ & $383 \pm 103$ & $440 \pm 103$ \\
\hline Run3\#6 & PST-9 & Pt & 0 & 3.50 & 93 & $\begin{array}{l}0.71 \pm 0.1 \\
0\end{array}$ & $279 \pm 75$ & $285 \pm 75$ \\
\hline
\end{tabular}

Experiment 4: 269 bars, duration: $4 \mathrm{~h}$

\begin{tabular}{|l|l|l|l|l|l|l|l|l|l|}
\hline Run4\#4 & VES-9 & Pt & 0 & 1.24 & 69 & $\begin{array}{l}0.85 \pm 0.0 \\
8\end{array}$ & $215 \pm 87$ & $212 \pm 87$ \\
\hline Run4\#5 & ETN-1 & Pt & 0 & 1.57 & 81 & $\begin{array}{l}0.95 \pm 0.1 \\
0\end{array}$ & n.d. & n.d. \\
\hline Run4\#6 & PST-9 & Pt & 0 & 1.00 & 72 & $\begin{array}{l}0.98 \pm 0.0 \\
7\end{array}$ & $73 \pm 31$ & $75 \pm 31$ \\
\hline
\end{tabular}

Experiment 19: 1,062 bars, duration: $5 \mathrm{~h}$

\begin{tabular}{|l|l|l|l|l|l|l|l|l|}
\hline $\begin{array}{l}\text { Run19\# } \\
1\end{array}$ & VES-9 & Pt & 0 & 3.16 & 74 & $\begin{array}{l}1.02 \pm 0.2 \\
3\end{array}$ & $\begin{array}{l}1,022 \pm 20 \\
4\end{array}$ & $\begin{array}{l}1,006 \pm 20 \\
4\end{array}$ \\
\hline $\begin{array}{l}\text { Run19\# } \\
2\end{array}$ & ETN-1 & Pt & 0 & 2.74 & 74 & $\begin{array}{l}1.51 \pm 0.3 \\
9\end{array}$ & $504 \pm 101$ & $578 \pm 101$ \\
\hline $\begin{array}{l}\text { Run19\# } \\
3\end{array}$ & PST-9 & Pt & 0 & 2.59 & 71 & $\begin{array}{l}0.91 \pm 0.1 \\
5\end{array}$ & $613 \pm 144$ & $626 \pm 144$ \\
\hline
\end{tabular}

${ }^{\mathrm{a}}$ Proportion of $\mathrm{FeO}$ kept in the glass relative to the initial glass $\mathrm{FeO}$ concentration, calculated as $100 * \mathrm{FeO}_{\text {glass }} / \mathrm{FeO}_{\text {starting glass, }}$ with $\mathrm{FeO}_{\text {starting glass }}$ from Table 1

${ }^{\mathrm{b}} \mathrm{H}_{2} \mathrm{O}$ determined by NIR-FTIR measurements (see text for explanation) 
${ }^{\mathrm{c}} \mathrm{CO}_{2}$ determined by MIR-FTIR measurements and calculated with Beer-Lambert law, using $\varepsilon_{1515}$ from Fine and Stolper (1986)

${ }^{\mathrm{d}} \mathrm{CO}_{2}$ determined by MIR-FTIR measurements and calculated with Beer-Lambert law, using $\varepsilon_{1515}$ from Dixon and Pan (1995) 
Table 3 Experimental results obtained on basalt from (a) Vesuvius, (b) Etna and (c) Stromboli

\begin{tabular}{|c|c|c|c|c|c|c|c|c|c|c|c|c|c|c|c|c|c|}
\hline $\begin{array}{l}P_{\text {tot }} \\
\text { (bar) }\end{array}$ & Run & $\mathrm{Na}_{2} \mathrm{O}+\mathrm{K}_{2} \mathrm{O}$ & $\begin{array}{l}\text { Density }^{a} \\
(\mathrm{~g} / \mathrm{l})\end{array}$ & $\begin{array}{l}\% \text { FeO } \\
\text { Kept }^{b}\end{array}$ & $\begin{array}{l}\text { wt\% } \% \\
\mathrm{H}_{2} \mathrm{O}_{\mathrm{mol}}\end{array}$ & $\begin{array}{l}\text { wt } \% \\
\text { OH }\end{array}$ & $\begin{array}{l}\mathrm{wt}^{2} \% \\
\mathrm{H}_{2} \mathrm{O}_{\text {tot }}\end{array}$ & $\begin{array}{l}\mathrm{CO}_{2} \\
(\mathrm{ppm})^{\mathrm{d}}\end{array}$ & e & f & g & $\mathrm{g}$ & h & h & $h$ & h & $\mathrm{i}$ \\
\hline \multicolumn{18}{|l|}{ (a) } \\
\hline \multirow{2}{*}{2,059} & \multirow{2}{*}{ Run1\#2 } & 7.99 & 2,696 & 68.36 & 0.36 & 0.44 & 0.80 & 2,094 & 87 & 3,128 & 0.041 & 0.959 & 1.61 & 0.73 & 1.76 & 0.17 & -5.991 \\
\hline & & 0.24 & 3 & & 0.07 & 0.01 & 0.16 & 431 & 17 & 612 & 0.008 & & & & & & \\
\hline \multirow{2}{*}{524} & \multirow{2}{*}{ Run3\#4 } & 7.81 & 2,692 & 83.10 & 0.27 & 0.55 & 0.82 & 582 & 91 & 482 & 0.174 & 0.826 & 1.65 & 0.55 & 2.20 & 0.05 & -5.952 \\
\hline & & 0.28 & 2 & & 0.12 & 0.02 & 0.37 & 132 & 40 & 217 & 0.078 & & & & & & \\
\hline \multirow{2}{*}{269} & \multirow{2}{*}{ Run4\#4 } & 8.01 & 2,692 & 69.32 & 0.27 & 0.58 & 0.85 & 215 & 96 & 183 & 0.359 & 0.641 & 1.71 & 0.53 & 2.35 & 0.02 & -5.903 \\
\hline & & 0.18 & 1 & & 0.02 & 0.04 & 0.08 & 87 & 9 & 30 & 0.048 & & & & & & \\
\hline \multirow{2}{*}{1,062} & \multirow{2}{*}{ Run19\#1 } & 7.60 & 2,689 & 73.71 & 0.36 & 0.66 & 1.02 & 1022 & 131 & 1,165 & 0.124 & 0.876 & 2.05 & 0.72 & 2.67 & 0.08 & -5.634 \\
\hline & & 0.16 & 2 & & 0.07 & 0.06 & 0.23 & 204 & 29 & 265 & 0.028 & & & & & & \\
\hline \multicolumn{18}{|l|}{ (b) } \\
\hline \multirow{2}{*}{2,059} & \multirow{2}{*}{ Run1\#4 } & 5.86 & 2,680 & 79.40 & 0.69 & 0.81 & 1.49 & 1429 & 216 & 2,926 & 0.103 & 0.897 & 2.99 & 1.37 & 3.22 & 0.12 & -5.198 \\
\hline & & 0.23 & 1 & & 0.06 & 0.02 & 0.13 & 299 & 19 & 256 & 0.009 & & & & & & \\
\hline \multirow{2}{*}{1,013} & \multirow{2}{*}{ Run2\# 8} & 5.84 & 2,679 & 69.84 & 0.80 & 0.74 & 1.55 & 661 & 231 & 967 & 0.229 & 0.771 & 3.09 & 1.61 & 2.97 & 0.05 & -5.141 \\
\hline & & 0.16 & 2 & & 0.10 & 0.06 & 0.23 & 142 & 34 & 145 & 0.034 & & & & & & \\
\hline \multirow{2}{*}{524} & \multirow{2}{*}{ Run3\#5 } & 5.68 & 2,694 & 82.50 & 0.34 & 0.38 & 0.73 & 383 & 58 & 519 & 0.111 & 0.889 & 1.47 & 0.69 & 1.55 & 0.03 & -6.341 \\
\hline & & 0.22 & 1 & & 0.09 & 0.02 & 0.20 & 103 & 16 & 145 & 0.031 & & & & & & \\
\hline \multirow{2}{*}{269} & \multirow{2}{*}{ Run4\#5 } & 5.57 & 2,690 & 81.42 & 0.55 & 0.41 & 0.95 & n.d. & 95 & 183 & 0.356 & 0.644 & 1.92 & 1.10 & 1.64 & n.d. & -5.909 \\
\hline & & 0.18 & 1 & & 0.04 & 0.03 & 0.10 & & 10 & 31 & 0.051 & & & & & & \\
\hline \multirow{2}{*}{1,062} & \multirow{2}{*}{ Run19\#2 } & 5.49 & 2,679 & 73.92 & 0.74 & 0.77 & 1.51 & 504 & 222 & 1,050 & 0.210 & 0.790 & 3.03 & 1.48 & 3.09 & 0.04 & -5.175 \\
\hline & & 0.18 & 4 & & 0.19 & 0.04 & 0.39 & 101 & 57 & 272 & 0.054 & & & & & & \\
\hline \multicolumn{18}{|l|}{ (c) } \\
\hline 2,059 & Run1\#6 & 4.51 & 2,678 & 69.61 & 0.66 & 0.92 & 1.58 & 1,170 & 285 & 2,820 & 0.136 & 0.864 & 3.16 & 1.32 & 3.69 & 0.10 & -4.959 \\
\hline
\end{tabular}




\begin{tabular}{|c|c|c|c|c|c|c|c|c|c|c|c|c|c|c|c|c|c|}
\hline $\begin{array}{l}P_{\text {tot }} \\
\text { (bar) }\end{array}$ & Run & $\mathrm{Na}_{2} \mathrm{O}+\mathbf{K}_{2} \mathrm{O}$ & $\begin{array}{l}\text { Density }^{a} \\
\text { (g/l) }\end{array}$ & $\begin{array}{l}\% \mathrm{FeO} \\
\text { kept }^{\mathrm{b}}\end{array}$ & $\begin{array}{l}\text { wt\% } \\
\mathrm{H}_{2} \mathrm{O}_{\text {mol }}\end{array}$ & $\begin{array}{l}\text { wt\% } \% \\
\text { OH }\end{array}$ & $\begin{array}{l}\text { wt\% } \% \\
\mathrm{H}_{2} \mathrm{O}_{\text {tot }}\end{array}$ & $\begin{array}{l}\mathrm{CO}_{2} \\
(\mathbf{p p m})^{\mathrm{d}}\end{array}$ & e & f & g & g & h & h & h & h & $\mathrm{i}$ \\
\hline & & 0.12 & 1 & & 0.06 & 0.03 & 0.16 & 277 & 28 & 286 & 0.014 & & & & & & \\
\hline \multirow{2}{*}{524} & \multirow{2}{*}{ Run3\#6 } & 4.36 & 2,694 & 93.22 & 0.30 & 0.41 & 0.71 & 279 & 71 & 504 & 0.136 & 0.864 & 1.43 & 0.61 & 1.66 & 0.02 & -6.165 \\
\hline & & 0.19 & 1 & & 0.04 & 0.01 & 0.10 & 75 & 10 & 81 & 0.021 & & & & & & \\
\hline \multirow{2}{*}{269} & \multirow{2}{*}{ Run4\#6 } & 4.49 & 2,689 & 71.69 & 0.32 & 0.66 & 0.98 & 73 & 124 & 152 & 0.465 & 0.535 & 1.98 & 0.65 & 2.65 & 0.01 & -5.678 \\
\hline & & 0.15 & 1 & & 0.06 & 0.02 & 0.17 & 31 & 22 & 33 & 0.091 & & & & & & \\
\hline \multirow{2}{*}{1,062} & \multirow{2}{*}{ Run19\#3 } & 4.49 & 2,691 & 71.07 & 0.34 & 0.57 & 0.91 & 613 & 109 & 1,192 & 0.103 & 0.897 & 1.83 & 0.69 & 2.28 & 0.05 & -5.791 \\
\hline & & 0.10 & 0 & & 0.05 & 0.04 & 0.15 & 144 & 18 & 205 & 0.018 & & & & & & \\
\hline
\end{tabular}


Table 4 Best-fit thermodynamic parameters for Eq. 17

\begin{tabular}{|c|c|c|c|c|c|c|c|c|c|}
\hline Composition & $\Delta V^{0}$ & \multicolumn{2}{|l|}{$0 \ln K_{0}$} & $P_{0}$ (bar) & $T_{0}\left({ }^{\circ} \mathrm{C}\right)$ & & & & \\
\hline VES-9 & 31 & \multicolumn{2}{|c|}{$-14.10 \pm 0.03$} & 1,000 & 1,200 & & & & \\
\hline ETN-1 & 23 & \multicolumn{2}{|c|}{$-14.55 \pm 0.00$} & 1,000 & 1,200 & & & & \\
\hline \multirow[t]{2}{*}{ PST-9 } & 6 & \multicolumn{2}{|c|}{$-14.74 \pm 0.01$} & 1,000 & 1,200 & & & & \\
\hline & & & \multicolumn{3}{|c|}{$V$ carbonate } & & & & \\
\hline \multicolumn{3}{|c|}{ Thibault et al. (1994) } & \multicolumn{3}{|c|}{ Leucitite } & 22 & & & \\
\hline \multicolumn{3}{|c|}{ Pan et al. (1991) } & \multicolumn{3}{|c|}{ Tholeiite } & $23 \pm 1.03$ & $-14.83 \pm 0.1$ & 1,000 & 1,200 \\
\hline \multicolumn{3}{|c|}{ Stolper and Holloway (1988) } & \multicolumn{3}{|c|}{ Tholeiite } & $33 \pm 0.5$ & $-15.15 \pm 0.06$ & 1,000 & 1,200 \\
\hline \multicolumn{3}{|c|}{ Stolper et al. (1987) } & \multicolumn{3}{|c|}{$\mathrm{NaA} 1 \mathrm{Si} 3 \mathrm{O} 8$} & 25 & & & \\
\hline \multicolumn{3}{|c|}{ Spera and Bergman (1980) } & \multicolumn{3}{|c|}{ Andesite CA } & 34 & & & \\
\hline \multicolumn{3}{|c|}{ Spera and Bergman (1980) } & \multicolumn{3}{|c|}{ Tholeiite K1921 } & 33 & & & \\
\hline \multicolumn{3}{|c|}{ Spera and Bergman (1980) } & \multicolumn{3}{|c|}{ Olivine Melilite OM1 2} & & & & \\
\hline
\end{tabular}


